\title{
Seasonal and interannual variability in algal biomass and primary production in the Mediterranean Sea, as derived from 4 years of SeaWiFS observations
}

\author{
E. Bosc, A. Bricaud, and D. Antoine \\ Laboratoire d'Océanographie de Villefranche, CNRS and Université Pierre et Marie Curie, Villefranche-sur-Mer, France
}

Received 14 January 2003; revised 26 June 2003; accepted 29 August 2003; published 10 January 2004.

[1] Because the Mediterranean has been subject for several decades to increasing anthropogenic influences, monitoring algal biomass and primary production on a longterm basis is required to detect possible modifications in the biogeochemical equilibrium of the basin. This work was initiated thanks to a 4-year-long time series of SeaWiFS observations. Seasonal variations of algal biomass (estimated using a previously developed regional algorithm) and primary production were analyzed for the various regions, and compared with those estimated using the CZCS sensor (1978-1986). Also, interannual variations could be assessed for the first time. The seasonal cycles of algal biomass generally reveal a maximum in winter or spring, and a minimum in summer. Some conspicuous differences with CZCS observations (e.g., in the Northwest Basin, reduction of the deep convection zone, earlier start of the spring bloom, quasi-absence of the vernal bloom) likely result from environmental changes. Interannual variations in algal biomass are noticeable all over the basin, including in the very oligotrophic waters of the Eastern Basin. The seasonal evolution of primary production is predominantly influenced by that of algal biomass in the Western Basin (with, in particular, a spring maximum). In the Eastern Basin, the seasonal courses of PAR and biomass tend to compensate each other, and primary production varies weakly along the year. The annual values computed over the 1998-2001 period for the Western Basin $\left(163 \pm 7 \mathrm{gC} \mathrm{m}^{-2}\right.$ $\left.\mathrm{yr}^{-1}\right)$ and the Eastern Basin $\left(121 \pm 5 \mathrm{gC} \mathrm{m}^{-2} \mathrm{yr}^{-1}\right)$ are lower (by 17 and $12 \%$, respectively) than those previously derived (using the same light-photosynthesis model) from CZCS data. INDEX TERMS: 4275 Oceanography: General: Remote sensing and electromagnetic processes (0689); 4806 Oceanography: Biological and Chemical: Carbon cycling; 4855 Oceanography: Biological and Chemical: Plankton; 4847 Oceanography: Biological and Chemical: Optics; KEYWORDS: algal biomass, Mediterranean Sea, ocean color, primary production, satellite, SeaWiFS

Citation: Bosc, E., A. Bricaud, and D. Antoine (2004), Seasonal and interannual variability in algal biomass and primary production in the Mediterranean Sea, as derived from 4 years of SeaWiFS observations, Global Biogeochem. Cycles, 18, GB1005, doi:10.1029/2003GB002034.

\section{Introduction}

[2] The Mediterranean Basin is a quasi-enclosed sea which has been extensively studied over the last decades, both because of local interest from the surrounding countries, and because it is often considered to be "a model of the world ocean itself," due to similarities in the processes of dense water formation, and in the thermohaline circulation [Lacombe, 1990]. While its hydrological and dynamical patterns have been known for a long time in the Western Basin [e.g., Lacombe and Tchernia, 1972], and more recently in the Eastern Basin [POEM Group, 1992], information about the spatial/temporal variations of algal biomass remained sparse until the first analyses of CZCS ocean color

Copyright 2004 by the American Geophysical Union. 0886-6236/04/2003GB002034 data. The Mediterranean is particularly well adapted to ocean color studies as the conditions of observation are optimal (low cloudiness), and also because turbid-case 2 waters, where the interpretation of ocean color is complex, are here of marginal areal extent, covering less than $5 \%$ of the whole basin [Antoine et al., 1995]. Therefore several studies based on ocean color were performed, mostly for restricted regions of the basin, such as the Alboran Sea and the Algerian Basin [e.g., Arnone et al., 1990] or the Levantine Basin [e.g., Gitelson et al., 1996; Van Dijken and Arrigo, 1996], but also at the scale of the basin. For the Western Basin, a systematic processing of CZCS scenes over the period 1979-1983 was conducted by Morel and André [1991]. This study allowed the seasonal evolution of both phytoplanktonic biomass and primary production (by operating a spectral light-photosynthesis model [Morel, 1991]), to be derived in the various regions of the Western Basin. This work was pursued for the 


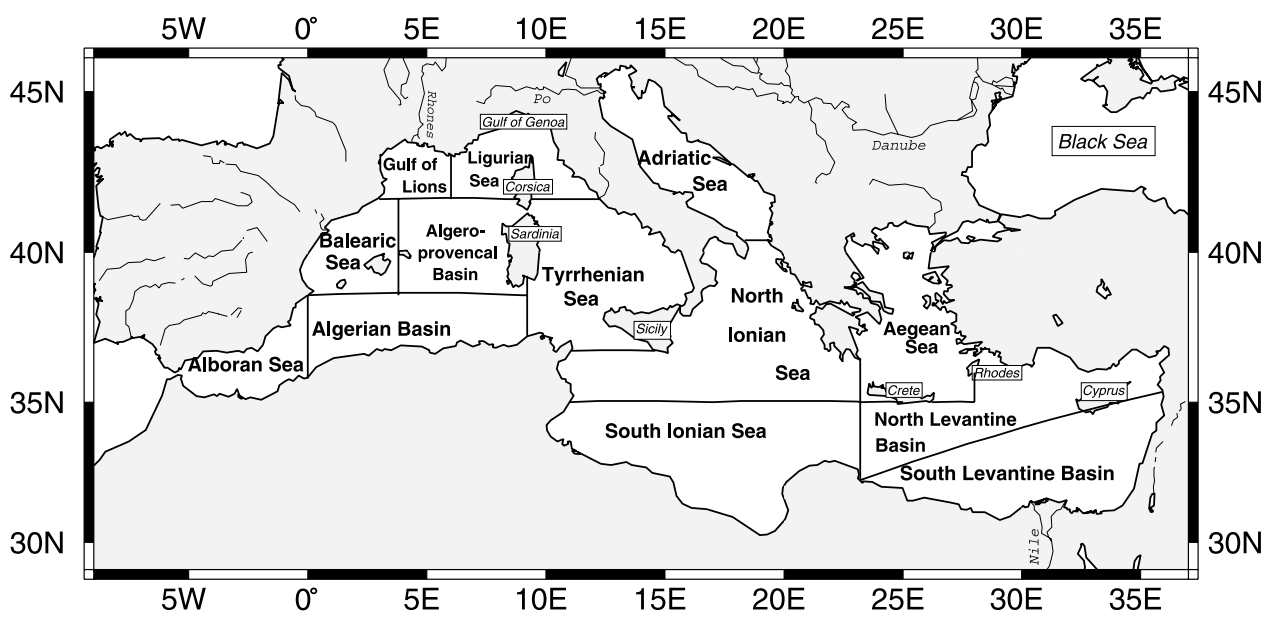

Figure 1. Map of the Mediterranean Basin and its 13 regions.

Eastern Basin [Antoine et al., 1995]. The combination of these works provided the first synoptic view, at the scale of the basin, of the spatial and seasonal variations in algal biomass and primary production, and of the corresponding carbon fluxes.

[3] In spite of the unexpected longevity of CZCS (which provided data over the period 1978-1986), however, both studies were limited by the insufficient frequency of acquisition of this sensor, and still more importantly, by the deficiencies in calibration and degradation in sensitivity [Evans and Gordon, 1994]. The analyses had to be restricted mostly to the period 1979-1981 (preceding the large drift in calibration) to ensure a reasonable radiometric accuracy. Over this period (and with selected additional scenes from 1982-1983), the available data had to be pooled together to reach a spatial/temporal coverage as complete as possible, so that no information on the interannual variability in algal biomass could be derived. Seasonal maps were therefore provided as "climatological" products.

[4] The availability of a long time series of SeaWiFS data now allows this study to be pursued, and improved in terms of temporal resolution. Owing both to the instrumental improvements (radiometric accuracy and sensitivity, accurately monitored calibration, availability of infrared channels, etc.) and to the successive advances in data processing, the data set provided by SeaWiFS is expected to be of significantly higher quality than the CZCS data set [see, e.g., McClain et al., 1998]. CZCS data, however, remain reliable, particularly with respect to the spatial patterns and their evolution along the year. Therefore the seasonal and interannual variations in algal biomass as observed by SeaWiFS can be analyzed, and also compared with those observed with CZCS some 20 years before. Such an analysis is particularly timely for an area which has been subject for a few decades to environmental changes (increasing anthropogenic inputs, and anthropogenic use of freshwater [see, e.g., Béthoux et al., 1999]) in addition to the possible effects of climatic evolution. These changes have already led to identified modifications in the water characteristics and circulation patterns. For instance, Roether et al. [1996] have observed an intrusion, over the past 10 years, of Aegean waters into the Eastern Mediterranean deep waters and a displacement of older waters upward, with likely consequences upon the primary production in the upper layer, the water exchange through the strait of Sicily, and the deep water production in the western Mediterranean. Béthoux et al. [1998] noted an increase of nitrate and phosphate concentrations in the Western Mediterranean deep waters by about $12 \%$ over the 1973-1994 period. Such changes are expected to affect the spatial distribution in biomass, primary production and the carbon budgets within the basin.

[5] The aims of this paper are (1) to analyze the spatial and seasonal variations of algal biomass and primary production as provided by SeaWiFS data, (2) to study the interannual variations over a more than 4-year-long time series, and to evaluate the annual carbon fixation and its variability, and (3) to compare the observed trends with those observed 20 years ago with the CZCS sensor. For this study, the Mediterranean Sea was schematically divided into 13 provinces as in the work by Bricaud et al. [2002], with a view to identifying possible regional peculiarities (Figure 1).

\section{Data and Methods}

\subsection{Ocean Color Data}

[6] The data used in this study were acquired by the Seaviewing Wide Field-of-view Sensor (SeaWiFS), launched by NASA aboard Seastar and which has been operating since September 1997. The main characteristics of this sensor are given by Hooker et al. [1992]. The products used for the present work are those resulting from reprocessing \#4, provided in July 2002 (see http://seawifs.gsfc. nasa.gov/SEAWIFS/RECAL/Repro4). Algorithms for atmospheric corrections are based on the studies by Gordon and Wang [1994] and Siegel et al. [2000], with some modifications. The bio-optical algorithm is the "OC4" algorithm proposed by O'Reilly et al. [1998], with revised numerical coefficients ("OC4v4"). It provides the (chlorophyll $a+$ pheophytin $a$ ) concentration from the "maximum reflectance ratio," $\rho=\log _{10}\left[\mathrm{R}_{\mathrm{rs}}(\lambda) / \mathrm{R}_{\mathrm{rs}}(555)\right]$, where $\mathrm{R}_{\mathrm{rs}}$ is the remote-sensing reflectance (i.e., the water-leaving radiance divided by the irradiance incident on the sea surface), 


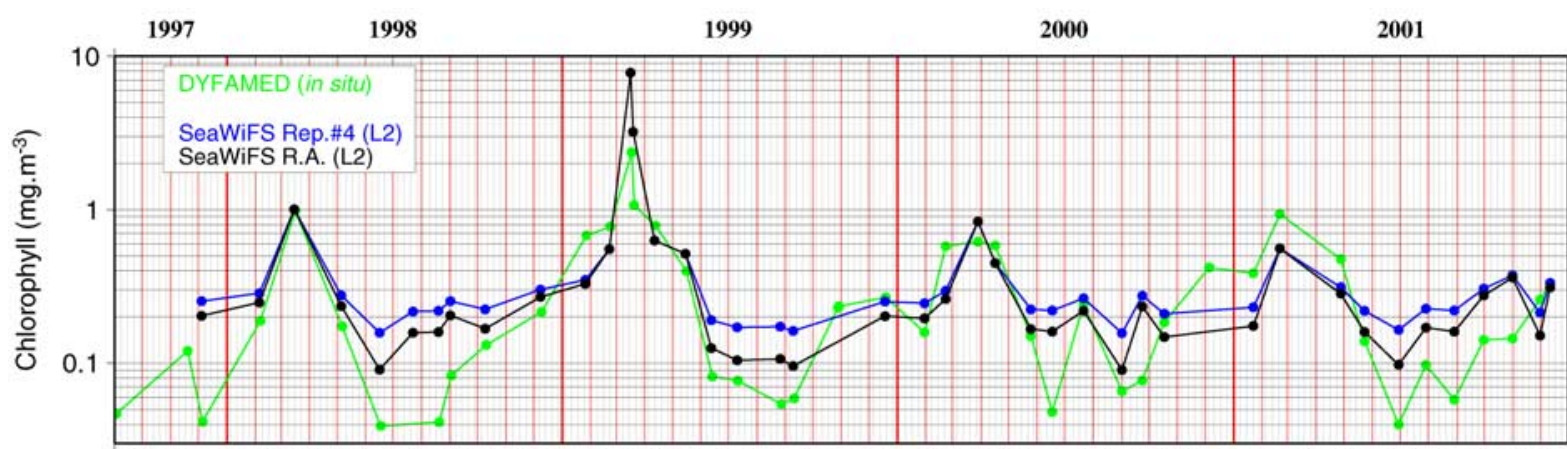

10

SONDJFMAMJJASONDJFMAMJJASONDJFMAMJJASONDJFMAMJJASOND

Figure 2. Comparison of the chlorophyll $a$ concentrations derived from SeaWiFS data with in situ HPLC measurements near the surface at the DYFAMED site (Liguro-Provençal Basin, 28 miles off the French coast; data courtesy of J. C. Marty and J. Ras) over the period September 1997 to December 2001. The SeaWiFS estimates are daily values at a resolution of $1 \mathrm{~km}$ (Level 1 LAC data, processed into Level 2 products using the NASA SeaDAS software). The three lines correspond to SeaWiFS estimates (reprocessing \#4, before and after correction using the regional algorithm) and in situ chlorophyll concentrations.

and $R_{r s}(\lambda)$ is the highest value among $R_{r s}(443), R_{r s}(490)$, and $\mathrm{R}_{\mathrm{rs}}(510)$,

$$
\text { Chl } a\left(\mathrm{mg} \mathrm{m}^{-3}\right)=10^{0.366-3.067 \rho+1.930 \rho^{2}+0.649 \rho^{3}-1.532 \rho^{4}} \text {. }
$$

[7] The products used in this study ("level 3" products, provided by the NASA Goddard Distributed Archive Center) are chlorophyll (chl) concentrations, averaged over 8 days, spatially binned (the surface of bins is $8.5 \times 8.5 \mathrm{~km}^{2}$ at the latitude of Gibraltar), and mapped onto a grid regularly spaced in latitude/longitude. The data for the Mediterranean were extracted from these Level-3 products using the NASA SeaDAS software (version 4.0), and were arranged as $484 \times 184$ pixel arrays. Then "masks" corresponding to the whole Mediterranean Basin (except the Black Sea, which was excluded) or to one of its provinces were applied. Finally, in each region, turbidCase 2 waters were discarded by applying a constant mask, defined as described by Bricaud et al. [2002]. Although the extension of turbid waters is expected to be variable with time, the use of such a constant mask allows the spatial means to be computed over fixed areas.

[8] These 8-day averaged chlorophyll concentrations were used in two ways: They were arithmetically averaged to derive the spatial means over the various regions, or they were used, pixel by pixel, as input parameters in a lightphotosynthesis model for estimating primary production for the corresponding pixel and the concerned period. For such computations, the 8-day chlorophyll averages have been preferred to daily products, because primary production computations can be performed only for pixels with clearsky conditions. This may introduce a large bias in daily primary production values, and result in an overestimate for the time-averaged primary production [see Bricaud et al., 2002]. When 8-day averages were incomplete because of cloud cover, gaps were filled with monthly averages for further computations.
[9] Data from the Coastal Zone Color Scanner were also used in this study. Two sets of climatological monthly averages of algal biomass were considered: (1) those extracted from the NASA global archive ("standard processing," using the empirical algorithms of Gordon et al. [1983]), and (2) those computed by Morel and André [1991] and Antoine et al. [1995], using a pixel-by-pixel iterative procedure, and bio-optical algorithms derived from a semianalytic model [André and Morel, 1991]. For both data sets, the bio-optical algorithms were providing the (chlorophyll $a+$ pheophytin $a$ ) concentrations ("pigment algorithms").

\section{2. "Regional" Bio-Optical Algorithm}

[10] In a previous study [Claustre et al., 2002], it was shown that the relationship between the chlorophyll $a$ concentration and the blue-to-green reflectance ratio $(\mathrm{R}(443) / \mathrm{R}(555))$, as measured at sea during the PROSOPE cruise in the Mediterranean, departed significantly from the OC4v4 algorithm at low chlorophyll concentrations $\left(<0.4 \mathrm{mg} \mathrm{m}^{-3}\right)$, possibly as a result of the input into seawater of desert dust brought by episodic "red rains." Similar biases have been observed in the Eastern Mediterranean, off the Israeli coast [Gitelson et al., 1996], and very recently in the northwest Mediterranean and in the Ionian Sea [see D'Ortenzio et al., 2001, 2002], as well as in the Alboran Sea [Corsini et al., 2002]. This suggests that this peculiarity could exist over large areas and periods. As a consequence, SeaWiFS chlorophyll estimates (as well as those provided by other ocean color sensors), when compared with in situ chlorophyll measurements, appear systematically overestimated in the oligotrophic areas of the basin [Bricaud et al., 2002]. Note that this latter study was using SeaWiFS data provided by reprocessing \#3. However, this bias is still observed with data from reprocessing \#4 (see Figure 2), which was expected since the same bio-optical algorithm (OC4v4) is involved. A "regional algorithm," obtained by regression analysis on a set of 

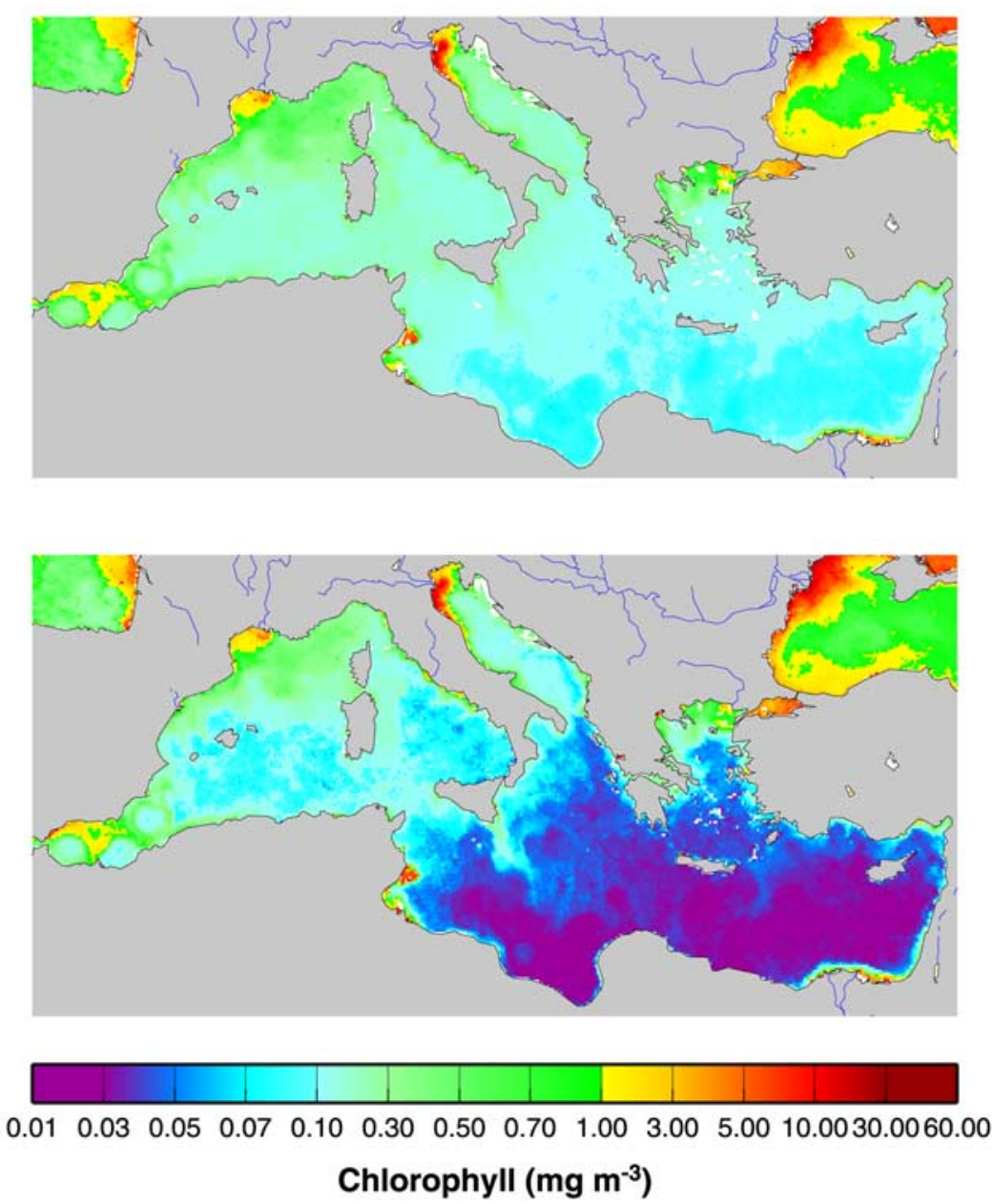

Figure 3. Monthly map (May 1999) of the chlorophyll concentrations derived from SeaWiFS data, according to (top) the OC4v4 algorithm and (bottom) the regional algorithm.

simultaneous in situ measurements of reflectance and (chlorophylla + pheophytin $a$ ) concentration, was therefore proposed by Bricaud et al. [2002],

$$
\text { Chl } a\left(\mathrm{mg} \mathrm{m}^{-3}\right)=2.094\left(\mathrm{R}_{\mathrm{rs}}(443) / \mathrm{R}_{\mathrm{rs}}(555)\right)^{-2.357} \text {. }
$$

[11] This algorithm coincides with OC4v4 for chl $a$ concentrations $>0.4 \mathrm{mg} \mathrm{m}^{-3}$, while at lower concentrations, the deviation increases with decreasing chl $a$ concentrations (up to a factor of 2.5 for a chl $a$ concentration of $0.03 \mathrm{mg}$ $\mathrm{m}^{-3}$ ). Equation (2) can be used in a very simple way to perform a pixel-by-pixel correction of SeaWiFS chlorophyll estimates; this consists of converting the SeaWiFS Chl $a$ value into the measured blue-green ratio using equation (1), and then deriving a corrected Chl $a$ value from this ratio using equation (2). The resulting chlorophyll estimate, when this procedure is applied to spatially and temporally averaged chlorophyll concentrations (Level-3, 8-day or monthly products), is obviously approximate, but the error is believed to be much smaller than that attached to the use of the OC4v4 algorithm for the Mediterranean Basin.
[12] The comparison of SeaWiFS monthly chlorophyll maps before and after correction (see example in Figure 3) demonstrates the ability of this regional algorithm to retrieve the very low chlorophyll concentrations (particularly those of the Eastern Basin) more realistically than the OC4v4 algorithm, even if they still remain substantially higher than in situ values. The comparison of reflectances derived from SeaWiFS and from in situ measurements has shown that this is mostly due to errors in atmospheric corrections (S. Hooker, unpublished data, 2000).

[13] It is emphasized here that the proposed correction remains tentative as long as the space and time extension of the phenomena inducing these peculiar optical properties of the Mediterranean are not better known. The reality of this bias, however, has been confirmed for various areas and periods (see above), and the biomass values provided by the regional algorithm have been found to be in better agreement with in situ measurements for oligotrophic waters (Figure 2). Therefore the corrected biomass estimates will be used hereinafter, in preference to those provided by the standard SeaWiFS products. In any case, the biomass values can be easily reconverted into those of the standard SeaWiFS 
Table 1. Chlorophyll Concentrations Provided by the Regional Algorithm (Chl (R.A.)), the NASA OC4v4 Algorithm (Chl (OC4v4)), and the CZCS Algorithm of André and Morel [1991] (Chl (AM 91), Also Used by Antoine et al. [1995], for Given Values of the BlueGreen Reflectance Ratio, $\mathrm{R}_{\mathrm{rs}}(443) / \mathrm{R}_{\mathrm{rs}}(555)^{\mathrm{a}}$

\begin{tabular}{cccccc}
\hline $\mathrm{R}(443) / \mathrm{R}(550)$ & $\mathrm{Chl}(\mathrm{R} . \mathrm{A}),. \mathrm{mg} \mathrm{m}^{-3}$ & $\mathrm{Chl}(\mathrm{OC} 4 \mathrm{v} 4), \mathrm{mg} \mathrm{m}^{-3}$ & $\mathrm{Chl}$ (AM 91), $\mathrm{mg} \mathrm{m}^{-3}$ & Chl (OC4v4)/Chl (R.A.) & Chl (AM 91)/Chl (R.A.) \\
\hline 6.10 & 0.03 & 0.076 & 0.034 & 2.57 & 1.16 \\
5.35 & 0.04 & 0.095 & 0.051 & 2.35 & 1.26 \\
4.88 & 0.05 & 0.109 & 0.066 & 2.03 & 1.31 \\
4.50 & 0.06 & 0.122 & 0.081 & 1.91 & 1.34 \\
4.22 & 0.07 & 0.134 & 0.095 & 1.81 & 1.35 \\
4.00 & 0.08 & 0.144 & 0.108 & 1.36 \\
3.80 & 0.09 & 0.155 & 0.122 & 1.64 & 1.35 \\
3.63 & 0.10 & 0.210 & 0.196 & 1.39 & 1.31 \\
3.06 & 0.15 & 0.252 & 0.253 & 1.25 & 1.26 \\
2.70 & 0.20 & 0.331 & 0.355 & 1.10 & 1.18 \\
2.28 & 0.30 & 0.412 & 0.452 & 1.03 & 1.13 \\
2.02 & 0.40 & 0.967 & 1.023 & 0.97 & 1.02 \\
1.37 & 1.00 & 1.531 & 1.538 & 1.02 & \\
1.15 & 1.50 & & & & 1.02 \\
\hline
\end{tabular}

${ }^{\mathrm{a}}$ The conversion factors between $\mathrm{Chl}$ (OC4v4), Chl (AM 91), and Chl (R.A.) are also indicated. Although the CZCS algorithm was expressed with respect to reflectance (instead of remote sensing reflectance), no correction was made on the blue-green ratio, as the CZCS processing was assuming that the upwelling irradiance-to-radiance ratio was spectrally independent.

products by using the factors provided in Table 1 (straightforwardly obtained by combining equations (1) and (2)).

\subsection{Computation of Primary Production}

[14] The model of Morel [1991], as adapted by Antoine and Morel [1996], allows the primary production within the upper layer to be computed from the surface chlorophyll concentration measured by an ocean color sensor. It is based on the general equation [Morel and Berthon, 1989]

$$
P=(1 / 39) \operatorname{PAR}\left(0^{+}\right) \mathrm{Chl}_{\mathrm{tot}} \Psi^{*},
$$

where $\mathrm{P}$ is the net carbon fixation within the productive layer (in $\mathrm{gC} \mathrm{m}^{-2}$ ) over a given time interval, $\operatorname{PAR}\left(0^{+}\right)$is the photosynthetically available radiant energy (integrated over the spectral range $400-700 \mathrm{~nm}$ ), at the sea level, per unit of surface $\left(\mathrm{J} \mathrm{m}^{-2}\right)$ and over the same time interval; $\mathrm{Chl}_{\text {tot }}$ is the column-integrated chlorophyll content $\left(\mathrm{g} \mathrm{Chl} \mathrm{m}^{-2}\right)$, and $\Psi^{*}$ represents the cross section for photosynthesis per unit of areal chlorophyll $\left(\mathrm{m}^{2}(\mathrm{~g} \mathrm{Chl})^{-1}\right)$. The factor $(1 / 39)$ expresses that the fixation of $1 \mathrm{mg}$ of carbon corresponds to an energy storage of $39 \mathrm{~J}$. It is recalled here that (1) this model deals only with particulate carbon fixation, (2) the model is diagnostic, and cannot predict the evolution of biomass with time: It computes the net carbon fixation by a given algal biomass, which results from the past history of the water mass (in terms of light, nutrients, production, grazing, etc.). Therefore the various terms appearing in equation (3) and their variations with time are actually interdependent.

[15] In practice, the computation uses look-up tables providing $\Psi^{*}$, with date, latitude, PAR at the sea level (or PAR above the atmosphere, combined with cloudiness), surface chlorophyll concentration $\left(\mathrm{Chl}_{\text {sat }}\right)$, and the average temperature of the productive layer (taken as 1.5 times the euphotic layer) as input parameters. The chlorophyll content of the water column $\left(\mathrm{Chl}_{\text {tot }}\right)$ is computed from the satellite value $\left(\mathrm{Chl}_{\text {sat }}\right)$ for two different situations: uniform or stratified biomass vertical profiles; the choice of a stratified profile is made when the monthly climatological value of the mixed layer depth, as provided by Levitus [1982], is lower than that of the euphotic depth (derived from $\mathrm{Chl}_{\text {sat }}$ [Morel, 1988]).

\subsection{PAR Data}

[16] Monthly and 8-day averages of the photosynthetically available radiant energy at the sea level, $\operatorname{PAR}\left(0^{+}\right)$, derived from SeaWiFS measurements by using an algorithm proposed by R. Frouin et al. (Algorithm to estimate PAR from SeaWiFS data, version 1.2 documentation, 2001, available at http://seawifs.gsfc.nasa.gov/SEAWIFS/RECAL/Repro4/ par/docs/seawifs_par_wfigs.pdf), are provided by the SeaWiFS Project. In most provinces and periods, the SeaWiFS estimates are in excellent agreement with the climatological $\operatorname{PAR}\left(0^{+}\right)$estimates (PAR values for a clear sky, combined with cloudiness averages from the ISCCP Project, [Rossow et al., 1996]) (see Figure 4). For given periods, however,
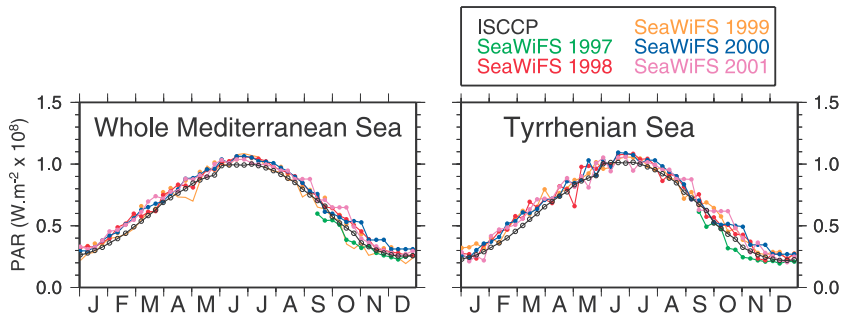

Figure 4. Eight-day averages of the photosynthetically available radiant energy at the sea level, PAR $\left(0^{+}\right)$, derived from SeaWiFS measurements using the algorithm of R. Frouin et al. (Algorithm to estimate PAR from SeaWiFS data, version 1.2 documentation, 2001, available at http:// seawifs.gsfc.nasa.gov/SEAWIFS/RECAL/Repro4/par/docs/ seawifs_par_wfigs.pdf), over the period September 1997 to December $\overline{2001}$, for the whole basin and for one region shown as an example. The climatological values (obtained by combining the PAR values for a clear sky with the cloudiness values provided by the ISCCP project [see Antoine et al., 1995]) are shown for comparison (black line). 
interannual variations of the weekly PAR values may reach 50\% (e.g., from October 1997 to October 2001), and therefore may still be much higher on a pixel-by-pixel basis. Accordingly, the SeaWiFS PAR products, which offer the advantage to be simultaneous to the Level-3 chlorophyll maps, have been used for primary production estimates, in preference to the climatological products previously used [see, e.g., Antoine et al., 1995].

\subsection{Seawater Temperature Data}

[17] Seawater temperature within the euphotic layer rules some photosynthetic parameters such as the assimilation number (maximum photosynthetic rate per unit of biomass), and therefore is an input parameter for the estimate of the cross section of photosynthesis, $\Psi^{*}$, when operating the light-photosynthesis model (see above). In this study we have used the "Reynolds analyses" [Reynolds and Smith, 1995], which provide weekly averages of sea surface temperature (SST) from January 1982 to the present on a $1^{\circ} \times 1^{\circ}$ grid. These analyses, which are derived from AVHRR data, present the advantage to be blended with in situ measurements, and to be almost coincident with the SeaWiFS Level-3 products (except that averages are computed every week instead of every 8 days). With a view to operating the light-photosynthesis model, however, it remains necessary to extrapolate these SST data to the average temperatures of the productive layer (noted $\left.\mathrm{T}_{1.5 \mathrm{ze}}\right)$. For this we have combined the Reynolds analyses with the climatological data set of Levitus, using the procedure described by Bricaud et al. [2002]. $\mathrm{T}_{1.5 \mathrm{ze}}$ may experience fairly high interannual variations (e.g., about $4^{\circ}$ from September 1997 to September 1998 in the Ligurian Sea; see Figure 5). Such a variability was also observed (for SST) in the Eastern Mediterranean by Marullo et al. [1999].

[18] Therefore the use of both seawater temperature and PAR $\left(0^{+}\right)$data in coincidence with SeaWiFS 8-day products are expected to provide more accurate estimates of primary production than the use of climatological data. It is also interesting to note that the period of the maximum in seawater temperature (end of August to beginning of September) is shifted by about 2 months with respect to the maximum in $\operatorname{PAR}\left(0^{+}\right)$(end of June), which could induce a broadening of the maximum in primary production (see later).

\section{Results and Discussion}

\subsection{Seasonal Variability in Algal Biomass}

[19] The SeaWiFS monthly chlorophyll maps, as corrected using the regional algorithm, are shown as examples for 1999 (Figure 6). Chlorophyll maps for the other years are given by Bosc [2002]. As explained before, they reveal spatial patterns which are similar to those observed on the standard Level-3 products, except that all chl $a$ concentrations below $0.4 \mathrm{mg} \mathrm{m}^{-3}$ are shifted toward lower values. At the scale of the whole basin, the spatial means show a marked seasonal cycle, with the highest values in winter, from December to March $\left(0.25-0.40 \mathrm{mg} \mathrm{m}^{-3}\right)$ and a minimum (around $0.07 \mathrm{mg} \mathrm{m}^{-3}$ ) from June to September (Figure 7, top right panel). When considering the individual hydrological regions (Figures 6 and 7), however, there
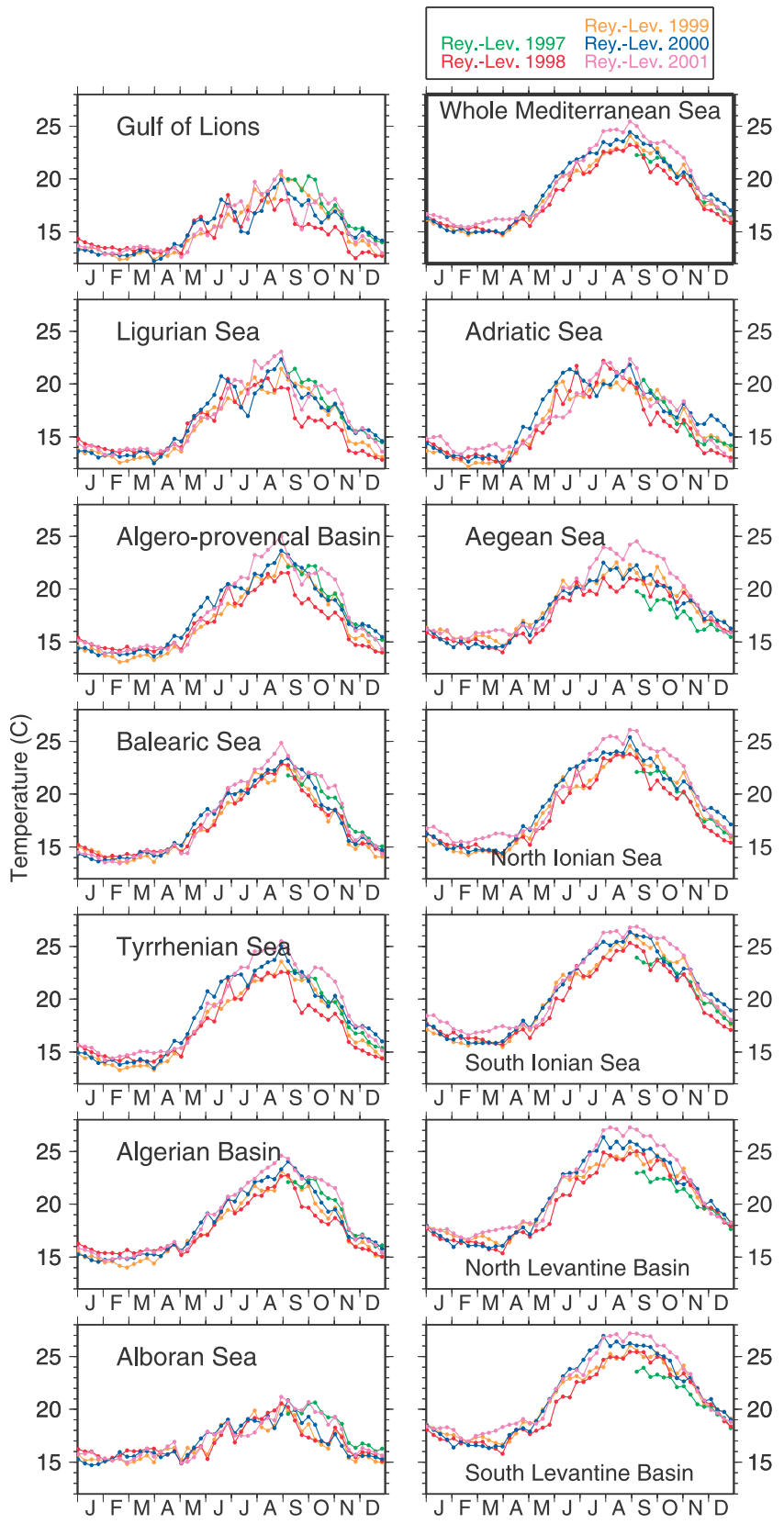

Figure 5. Weekly values of the average temperature of the productive layer, over the period September 1997 to December 2001, and for the various regions. These temperatures are obtained by combining the weekly "Reynolds analyses" for sea surface temperature [Reynolds and Smith, 1995] and the Levitus climatological profiles, using the procedure described by Bricaud et al. [2002].

appear significant differences in the seasonal cycles of algal biomass, as described below.

\subsubsection{Northwestern Basin}

[20] This region includes the Gulf of Lions, the Ligurian Sea, and the northern parts of the Balearic Sea, AlgeroProvençal Basin, and Tyrrhenian Sea. This area is known to be affected by a permanent cyclonic circulation of surface waters, inducing frontal structures with well-marked color 


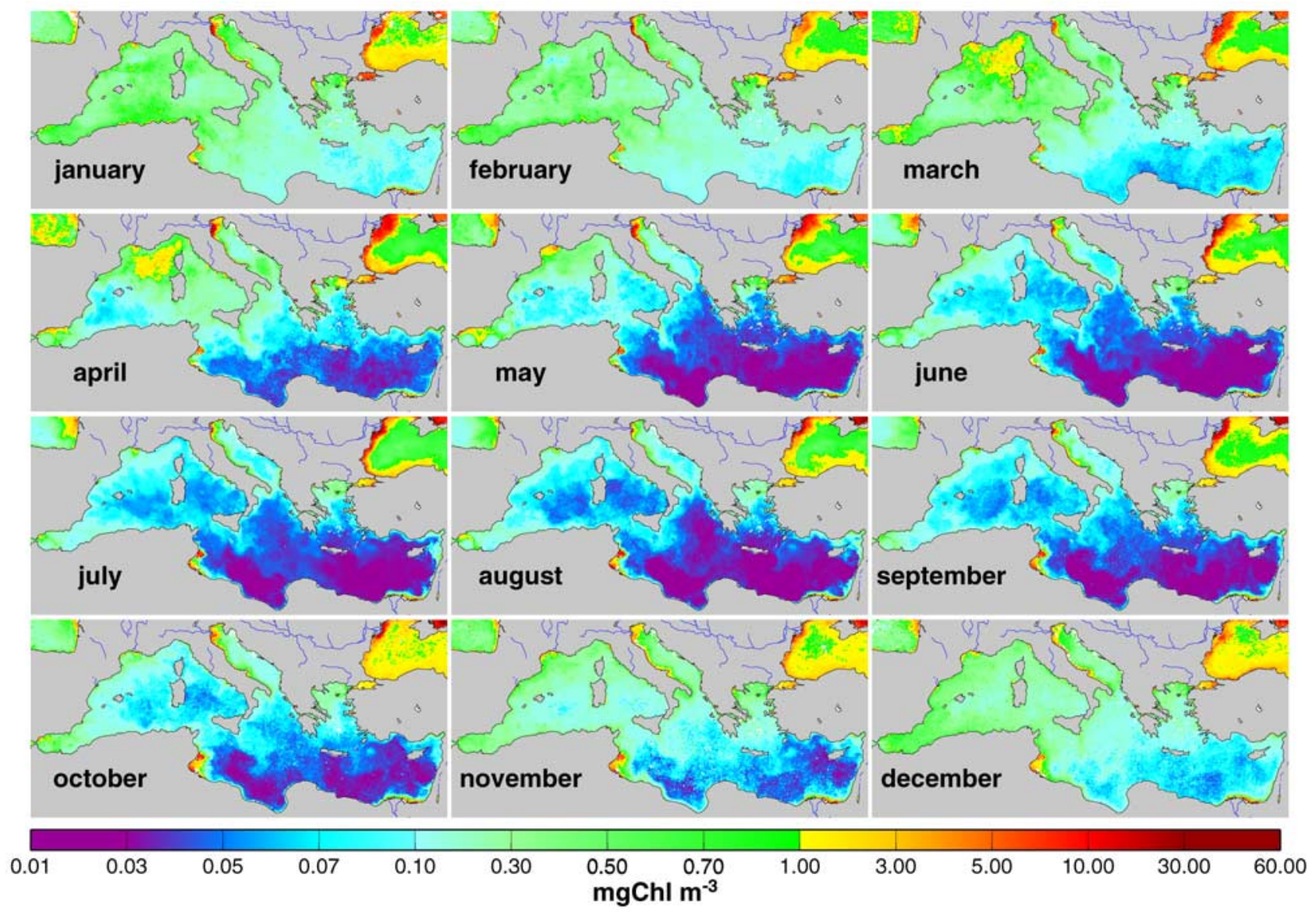

Figure 6. Monthly chlorophyll maps derived from SeaWiFS data (reprocessing \#4), after correction using the regional algorithm, for the year 1999.

signatures, particularly in the northern part (Ligurian Sea and Gulf of Lions). The central part of this northern area is the site of intense vertical convections in winter, especially south of the Gulf of Lions. This zone is easily recognized as a "clear spot" on the SeaWiFS chlorophyll maps in January and February 1999 (Figure 6), with chl $a$ concentrations around $0.06-0.10 \mathrm{mg} \mathrm{m}^{-3}$, and is observed as well at the beginning of 2000 and 2001 (not shown). The Northwestern Basin is also known to be subject to an intense bloom in spring, when the surface layer stabilizes, and sometimes to a less intense bloom in autumn, when the thermocline is progressively eroded.

[21] These features, known for a long time thanks to in situ measurements, have been described in more detail with respect to their spatial and temporal extension using CZCS observations [Morel and André, 1991]. The main patterns described in this earlier study are confirmed by the present SeaWiFS time series. With respect to the earlier observations, however, several differences appear. It is recalled here that the SeaWiFS and CZCS processings are not identical and may result in systematic differences in the chlorophyll estimates. While the chl values provided by the CZCS algorithm [André and Morel, 1991] and the SeaWiFS regional algorithm are in good agreement in the range $0.03-1.5 \mathrm{mg} \mathrm{m}^{-3}$ (see Table 1), atmospheric correction procedures are substantially different. In addition, winter values for CZCS have been constrained over given areas to overcome the calibration uncertainties [Antoine et al., 1995]. Therefore, while differences in spatial patterns likely indicate actual changes, moderate disparities in the chlorophyll concentrations must be considered with caution. The main divergences are the following:

[22] 1. According to CZCS observations, the winter period (January-February) was characterized by very low concentrations $\left(<0.08 \mathrm{mg} \mathrm{m}^{-3}\right)$ over the whole area, whereas the SeaWiFS data reveal, with the exception of the deep convection zone, more than fourfold higher concentrations ( 0.3 to $0.5 \mathrm{mg} \mathrm{m}^{-3}$ on average, Figure 7$)$. Note that the overestimate of SeaWiFS chlorophyll values, still remaining in some occasions (even when using the regional algorithm) and attributable to errors in atmospheric corrections, is about a factor of 2 (see Figure 2), and therefore cannot explain this discrepancy. Additionally, the deep convection zone appears much more restricted in size on the 4-year SeaWiFS time series (see, e.g., Figure 6) than on the CZCS image shown by Morel and André [1991, Plate 1].

[23] 2. The spring bloom, which was observed on CZCS data to start at mid-April and to be maximum in early May, appears repeatedly, over the 4 years of SeaWiFS data, to start at the end of February and to end at the beginning of May (Figures 6 and 7). Note also that the maximum appears slightly earlier (beginning of February) in the Algero- 


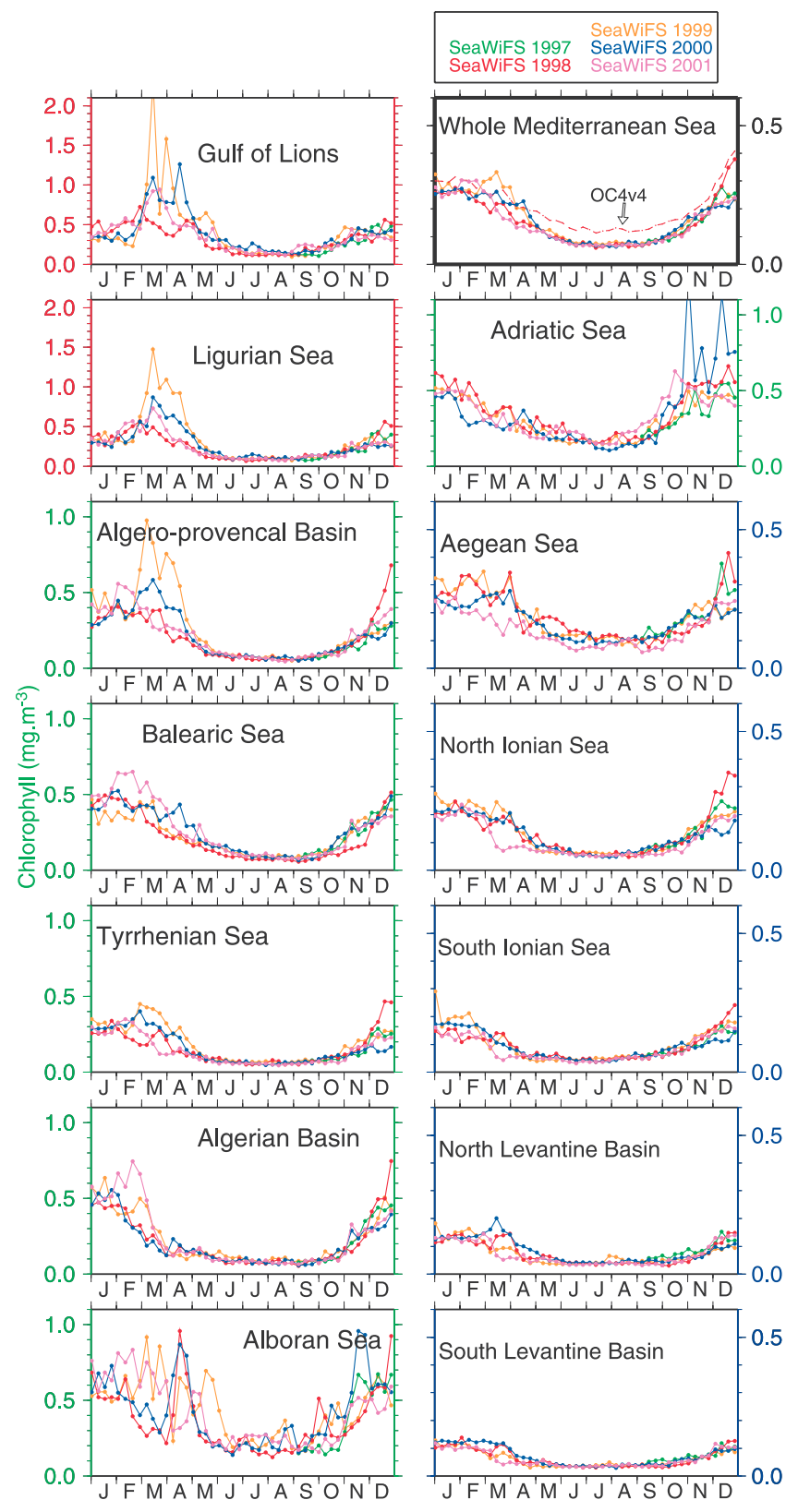

Figure 7. Eight-day averages of the chlorophyll concentrations derived from SeaWiFS data (reprocessing \#4), corrected using the regional algorithm, and averaged over the whole basin (top right panel) and the various regions, along the period September 1997-December 2001. Note that three different scales have been used. The averages obtained with the OC4v4 algorithm (i.e., without correction) are shown for comparison (dashed line) for the whole basin and the year 1998 .

Provençal Basin than in the Gulf of Lions and Ligurian Sea (end of February). This maximum is also of very variable intensity from year to year (see later, interannual variations), and is even virtually absent in some occasions (e.g., in 1998 in the Ligurian Sea).
[24] 3. From June to August, the SeaWiFS chl $a$ concentrations are consistently lower than in winter $(0.1-$ $0.2 \mathrm{mg} \mathrm{m}^{-3}$ on average in the northern part, $0.07-$ $0.10 \mathrm{mg} \mathrm{m}^{-3}$ in the southern part), while according to CZCS observations, concentrations were about threefold higher in August than in winter $\left(0.2-0.3 \mathrm{mg} \mathrm{m}^{-3}\right.$ on average, and up to $0.5 \mathrm{mg} \mathrm{m}^{-3}$ in the central parts of the gulfs of Lions and Genoa [Morel and André, 1991]).

[25] 4. SeaWiFS data reveal no well-marked (i.e., spatially and temporally localized) autumn bloom as observed with CZCS, but rather a progressive increase of biomass from September to December.

[26] Note that the temporal evolution of chlorophyll, as observed from in situ measurements in the Ligurian Sea at the DYFAMED site (see Figure 2), confirms the above trends observed on SeaWiFS data (maximum of the spring bloom in March, biomass values lower in summer than in winter, and no autumn bloom).

\subsubsection{Southwestern Basin}

[27] We include in this region the Algerian Basin, the Alboran Sea, and the southern parts of the Balearic Sea, Algero-Provençal Basin, and Tyrrhenian Sea. The seasonal cycles of algal biomass in the Algerian Basin and Tyrrhenian Sea are rather similar to those observed in the Northwestern Basin, with high biomass values in winter, the presence of a bloom in spring (moderate in amplitude and variable with respect to the period of occurrence) and a minimum from June to October. In the Algerian Basin, weekly and monthly composites clearly show the enhancement of biomass induced by the circulation of the Modified Atlantic Waters along the Algerian coast, and the high dynamical activity related to this current. The Tyrrhenian Sea is the most oligotrophic area of the Western Basin, particularly in summer. The mention of "ultra-oligotrophy" for this area [Morel and André, 1991], however, has to be moderated when comparing the average chl values observed in summer $\left(\sim 0.06 \mathrm{mg} \mathrm{m}^{-3}\right)$ with those of the Southeastern Basin at the same period $\left(\sim 0.03 \mathrm{mg} \mathrm{m}^{-3}\right.$; see Figure 7). It can be noted also that the area of enhanced biomass at the east of the strait of Bonifacio (between Corsica and Sardinia) is a quasi-permanent feature on the SeaWiFS time series (see, e.g., Figure 6), while it was not observed in winter by Morel and André [1991].

[28] The seasonal cycle of algal biomass in the Alboran Sea is the most chaotic of the whole basin, and reveals a high interannual variability (Figure 7). The only reproducible feature over the 4 years is the summer minimum of biomass (around $0.20-0.25 \mathrm{mg} \mathrm{m}^{-3}$, i.e., a significantly higher biomass than in the other regions). The distribution of phytoplankton in this area is known to be ruled by the inflow of Atlantic waters into the Mediterranean Sea, according to one or two well-defined anticyclonic gyres or "arches" with clear color signatures [see, e.g., Preller, 1986], and also by the combined effects of horizontal advection, coastal and gyre-induced upwelling, and seasonal stratification [GarciaGorriz and Carr, 1999, 2001]. A conspicuous feature on the images is the presence, at the east of the first gyre, of an intense bloom of short duration in April 1998 and 2000 (8day composites reveal that it maintained during about 3 weeks), while in 1999 and 2001 it was less intense but spread 
over several months. The color signature of the western gyre is generally apparent even in winter, while it was not observed by André and Morel [1991] at the same period on CZCS images.

\subsubsection{Eastern Basin}

[29] This basin includes the six regions at the east of the strait of Sicily (see Figure 1). All the subregions in this basin, with the exception of the Adriatic Sea, are characterized by low concentrations all around the year $(0.03$ to $0.3 \mathrm{mg} \mathrm{m}^{-3}$ for spatial averages; see Figure 7), the lowest concentrations being observed in the Levantine Basin (with the exception of waters at the boundary of the Nile plume). The main spatial features observed by Antoine et al. [1995] on CZCS images are confirmed by the SeaWiFS time series, in particular the general gradient in algal biomass from north to south and from west to east of the Eastern Basin.

[30] In contrast to this earlier study, however, a marked seasonal cycle is observed in the various regions, with a decrease of the algal biomass by a factor up to 3-4 from winter to summer (e.g., for the Levantine Basin, from 0.12 to $0.03 \mathrm{mg} \mathrm{m}^{-3}$ on average; see Figure 7). This seasonal cycle is therefore different from that observed by Antoine et al. [1995], which showed only weak variations over the year for the Ionian Sea and the Levantine Basin [Antoine et al., 1995, Figure 2]. Therefore winter values provided by SeaWiFS data are about 3 times higher than those observed by CZCS (e.g., about 0.10 instead of $0.03 \mathrm{mg} \mathrm{m}^{-3}$ on average for the Levantine Basin), while summer values are in good agreement (around $0.03-0.04 \mathrm{mg} \mathrm{m}^{-3}$ for the same area). Note that a trend similar to that observed on SeaWiFS data (winter values higher than spring values) was noted for in situ chlorophyll measurements in winter 1995 and spring 1996 for a few stations of the Levantine Basin and the Ionian Sea [see Bricaud et al., 2002]. Moreover, chlorophyll concentrations measured in situ in these two areas and during these two periods were close to those provided by SeaWiFS (e.g., in the Levantine Basin, around 0.10$0.15 \mathrm{mg} \mathrm{m}^{-3}$ in January 1995 , around $0.05 \mathrm{mg} \mathrm{m}^{-3}$ in May 1996 [see Vidussi, 1998]). Summer minima and winter (or end of winter) maxima were also observed during field cruises by Dowidar [1984] off the Egyptian coast, by Azov [1986] and Berman et al. [1986] off the Israelian coast, and by Van Dijken and Arrigo [1996] on CZCS images (processed differently from those of Antoine et al. [1995]), for the Southeastern Basin. The winter maximum was attributed by these authors to a convective overturn of the water column, in contrast to strong stratification in summer.

[31] Some more particular features observed by Antoine et al. [1995], can also be compared with SeaWiFS observations:

[32] 1. The "ultra-oligotrophic cores" of the south Levantine Basin (corresponding to the Mersa-Matruh and Shikmona gyres [Ozsöy et al., 1993]) repeatedly appear from May to October on SeaWiFS images over the 4 years, with a high interannual variability in pigment concentrations.

[33] 2. The chlorophyll-rich, filament-like structure extending southeast of Sicily in spring, is also clearly apparent over the 4 years (although much weaker in 1998). In contrast, the spring bloom in the Ionian Sea mentioned by Antoine et al. [1995] is almost not apparent.
In addition, winter biomass values provided by SeaWiFS are, as in several other provinces, strongly enhanced compared to those observed with CZCS.

[34] 3. The north-south gradient in algal biomass in the Aegean Sea, mentioned by Antoine et al. [1995] as a quasipermanent feature, is fully confirmed by the SeaWiFS data, and continuously observed over the 4 years (the high biomass values in the northern part were attributed to the combined effects of river inputs and northerly winter winds).

[35] 4. The enhancement of biomass induced in spring by the cyclonic circulation within the "Rhodes gyre," south of the island of Rhodes, is also clearly observed in MarchApril 2000 and 2001, but is hardly detectable in spring 1998 and 1999. Chlorophyll concentrations are around $0.6 \mathrm{mg}$ $\mathrm{m}^{-3}$ in March $2000\left(0.5 \mathrm{mg} \mathrm{m}^{-3}\right.$ on CZCS data from March 1979 to 1981). While the color signature of this gyre was vanishing in autumn/winter on CZCS images, this signature appears clearly on SeaWiFS data, particularly in November 1999 and 2000.

[36] A last striking difference with CZCS observations is that the distinct biomass maximum observed in November for all the provinces of the Eastern Basin by Antoine et al. [1995, Figure 2] is not detectable on any of the 4 years on SeaWiFS data (Figure 7b), except for the Adriatic Sea (see below).

[37] The Adriatic Sea appears to be a particular case. The seasonal cycle of biomass is similar to those of other regions of the Eastern Basin (summer minimum and winter maximum), but exhibits much higher (with spatial averages exceeding $1 \mathrm{mg} \mathrm{m}^{-3}$ in winter) and more erratic values. Part of this variability probably originates from the highly variable extension of Case 2 waters (plumes of Pô, Adige, and Piave) in this area. The maximum of biomass $\left(1.3 \mathrm{mg} \mathrm{m}^{-3}\right)$ observed in November by Antoine et al. [1995] is still present, with a similar value, in 2000 (but not during the other years). Note also that the cyclonic gyre in the southern part (colder water of Levantine origin [see, e.g., Vidussi et al., 2001]) has a strong color signature in spring, particularly in March and April 1999 (Figure 6).

\subsection{Interannual Variability in Algal Biomass \\ 3.2.1. Western Basin}

[38] With the exception of the Gulf of Lions, Ligurian Sea, and Alboran Sea, the spatially averaged weekly means of algal biomass in the various provinces show a low interannual variability (S.D. 10-25\% over 1997-2001) from June to September (Figure 8). This stability is not surprising considering the oligotrophic character (average biomass value around $0.10 \mathrm{mg} \mathrm{m}^{-3}$ ) of these provinces in this season. The variability increases up to $40-50 \%$ (and even $60 \%$ in the Algero-Provençal Basin) in spring and at the beginning of winter. In the Gulf of Lions and the Ligurian Sea, as well as in the Alboran Sea, the variability is high the whole year around, up to 60 to $70 \%$ in spring.

[39] At the pixel level, the year-to-year variations may exceed a factor of 4 , as shown by the maps of the 1999-to1998, 2000-to-1999, and 2001-to-2000 biomass ratios (Figure 9). Note that these year-to-year variations may result not only from biomass variations at the pixel level, but also 


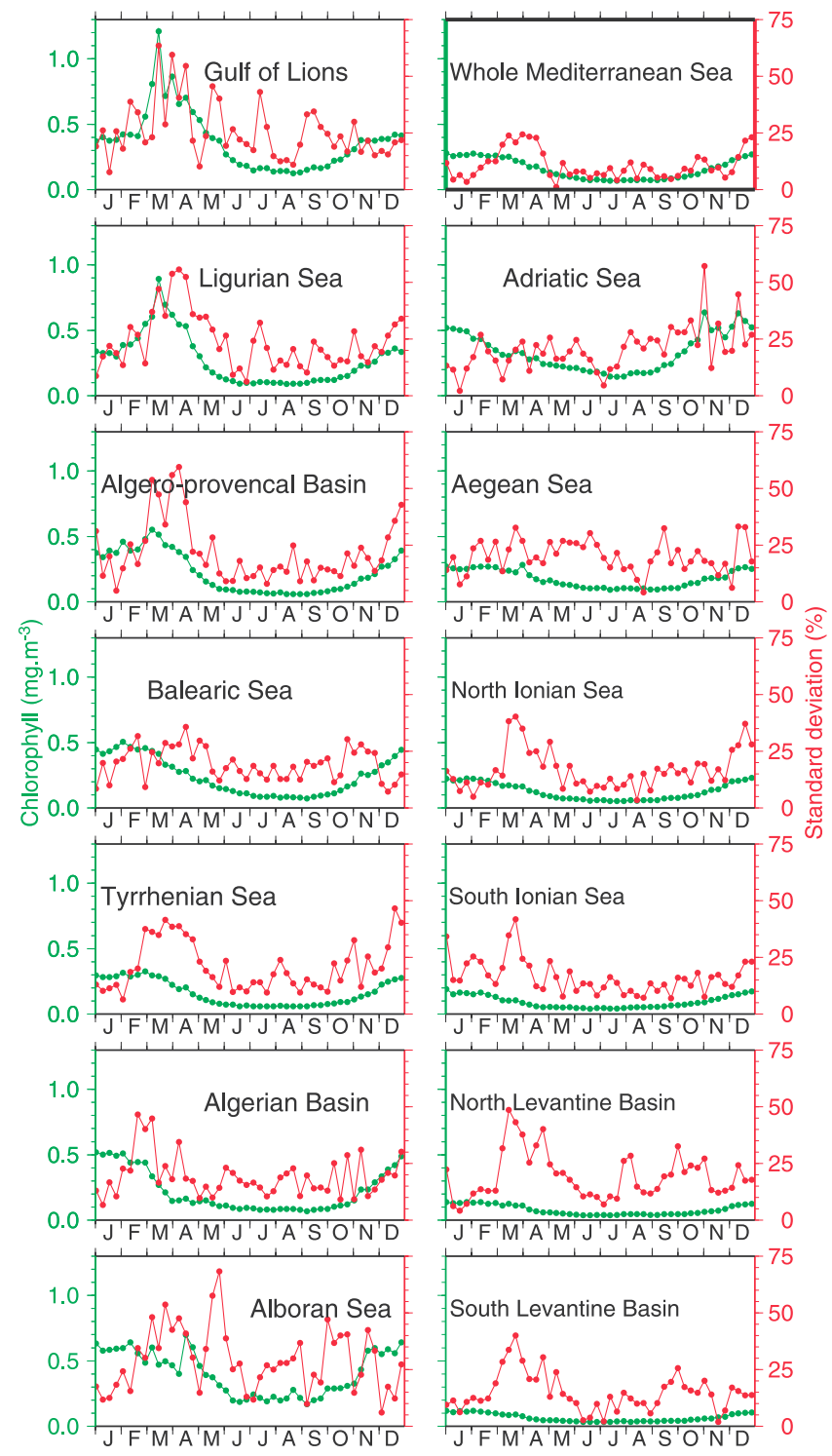

Figure 8. Eight-day averages of the chlorophyll concentrations derived from SeaWiFS data (as in Figure 7), and then averaged over the different years (green lines, in $\mathrm{mg} \mathrm{m}^{-3}$; left scales), for the whole basin and the various regions. The corresponding standard deviations are also shown (red lines, in \%; right scales).

from the displacement of biomass patterns. As a rule, the largest year-to-year differences appear to occur between 1998 and 1999, with a general increase in biomass over the Western Basin. The largest variations are observed in spring, particularly in the Tyrrhenian Sea, west of Corsica and Sardinia, and in the Alboran Sea. From 1999 to 2000, algal biomass shows an overall trend to decrease again, whereas from 2000 to 2001, it tends to increase in the southwestern provinces and to decrease in the Ligurian and Tyrrhenian Seas (by up to a factor of 3 in spring).

\subsubsection{Eastern Basin}

[40] Surprisingly, the interannual variability in the spatially averaged weekly means of algal biomass is not significantly lower than in the Western Basin, even in the most oligotrophic provinces (Ionian sea and Levantine Basin), often expected to be the most stable. As in the Western Basin, the year-to-year variability is lower in summer (S.D. 10-25\% over 1997-2001) and is higher (up to 50\%) in spring (Figure 8). A notable exception is the Adriatic Sea where the interannual variability is the highest in November-December.

[41] At the pixel level, the year-to-year variability may reach, as in the Western Basin, a factor up to 4 according to the year and province (Figure 9). A striking feature is that in many occasions, the year-to-year variations observed over the Eastern Basin are inverse to those for the Western Basin, with the most contrasted evolutions occurring in spring. From spring 1998 to spring 1999, biomass values decrease over large areas of the Eastern Basin by a factor of 1.5 to 2 (while they increase in the Western Basin). Inversely, they increase from 1999 to 2000 by a similar amount (the 2000/ 1998 biomass ratios reveal weak variations; not shown). Conversely, the year 2001, in comparison to the previous years, reveals exceptionally low biomass values over a large part of the Eastern Basin, particularly in spring (see also Figure 7). During this period, the average chl concentrations are as low as $0.02-0.03 \mathrm{mg} \mathrm{m}^{-3}$ both in the Levantine Basin and the Ionian Sea. Note also the strong color signature of the Rhodes gyre in spring 2000 compared to the other years (biomass values are more than fourfold higher than in 1999), and the exceptional bloom in the central part of the Adriatic Sea in fall 2001.

\subsection{Seasonal and Interannual Variations in Primary Production}

[42] The seasonal and interannual variations of primary production, computed for each 8-day period (from 8-day chlorophyll and PAR averages, and weekly seawater temperature data), and then spatially averaged over the various provinces, are shown in Figure 10. The monthly primary production maps (derived from the monthly chlorophyll, PAR, and seawater temperature data) are also shown as examples for 1999 (Figure 11). Primary productions maps for the other years are given by Bosc [2002].

[43] As shown by equation (3), the seasonal evolution of primary production is determined by the concurrent seasonal evolutions of the vertically integrated biomass content, $\mathrm{Ch}_{\text {tot }}$ (varying roughly as $\mathrm{Ch}_{\text {sat }}^{0.5}$ [see Morel and Berthon, 1989]) and of the term ( $\Psi^{*}$ PAR), where $\Psi^{*}$ combines the effects of chlorophyll, PAR, and seawater temperature in a complex way [see Antoine and Morel, 1996]. It was shown by Bricaud et al. [2002] that in the Mediterranean Basin, the seasonal variations of primary production are predominantly influenced by those of PAR and algal biomass, while seawater temperature variations have only a second-order effect.

[44] In the Western Basin, the seasonal evolution of primary production is mainly ruled by the spring maximum in biomass which occurs in most provinces (except in the Algerian Basin, where it is vanishing). Consequently, as already observed by Morel and André [1991], primary production shows also a maximum at this period (Figure 10). The exceptional bloom in the Ligurian Sea in spring 1999, 

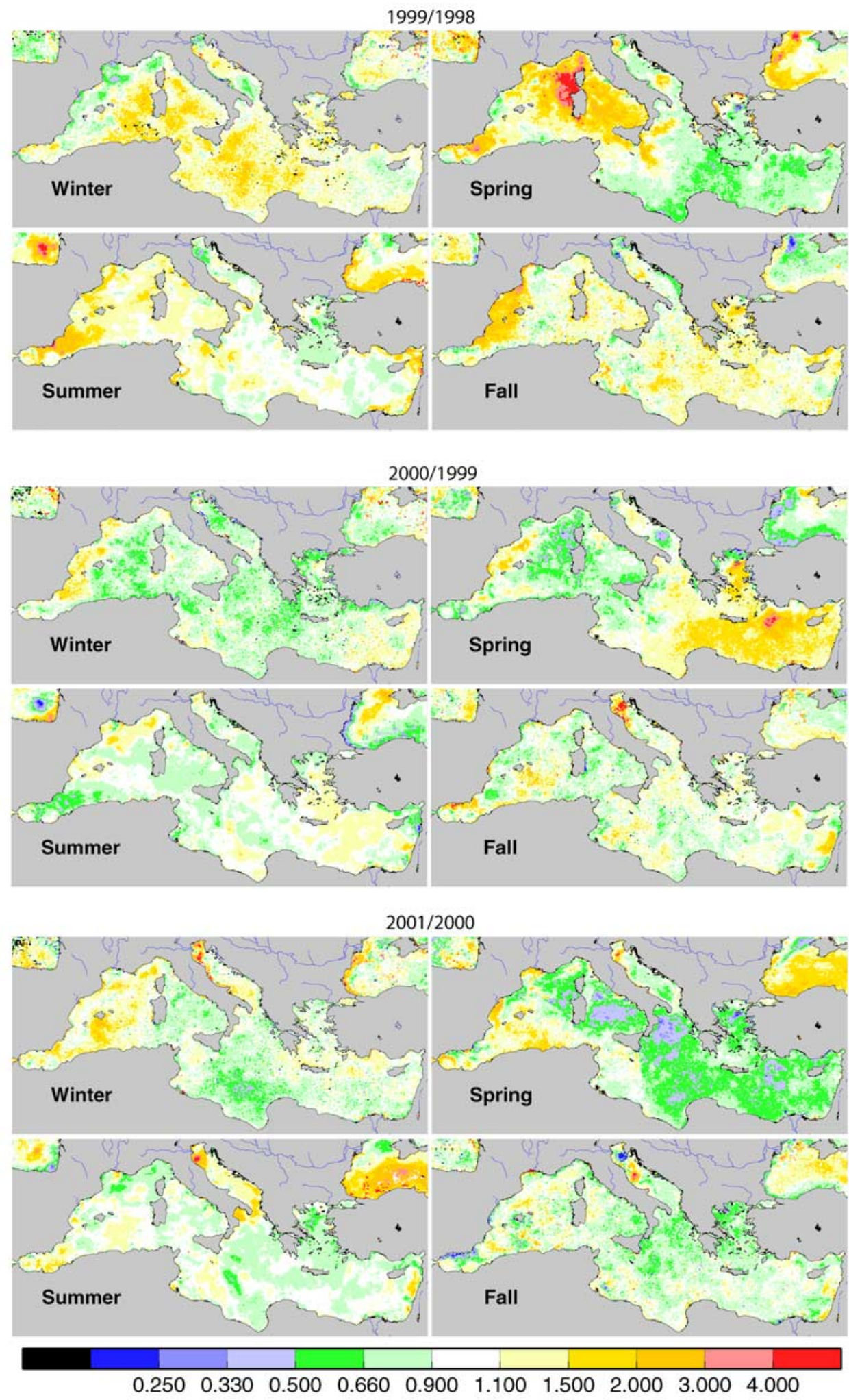

Figure 9. Year-to-year ratios of the chlorophyll concentrations derived from SeaWiFS data (reprocessing \#4, after correction using the regional algorithm), averaged over the four seasons. The values of this ratio are indicated on the color scale. Winter, spring, summer, and fall cover the periods December to February, March to May, June to August, and September to November, respectively. Black pixels indicate nonavailable values in at least one of the two maps. 


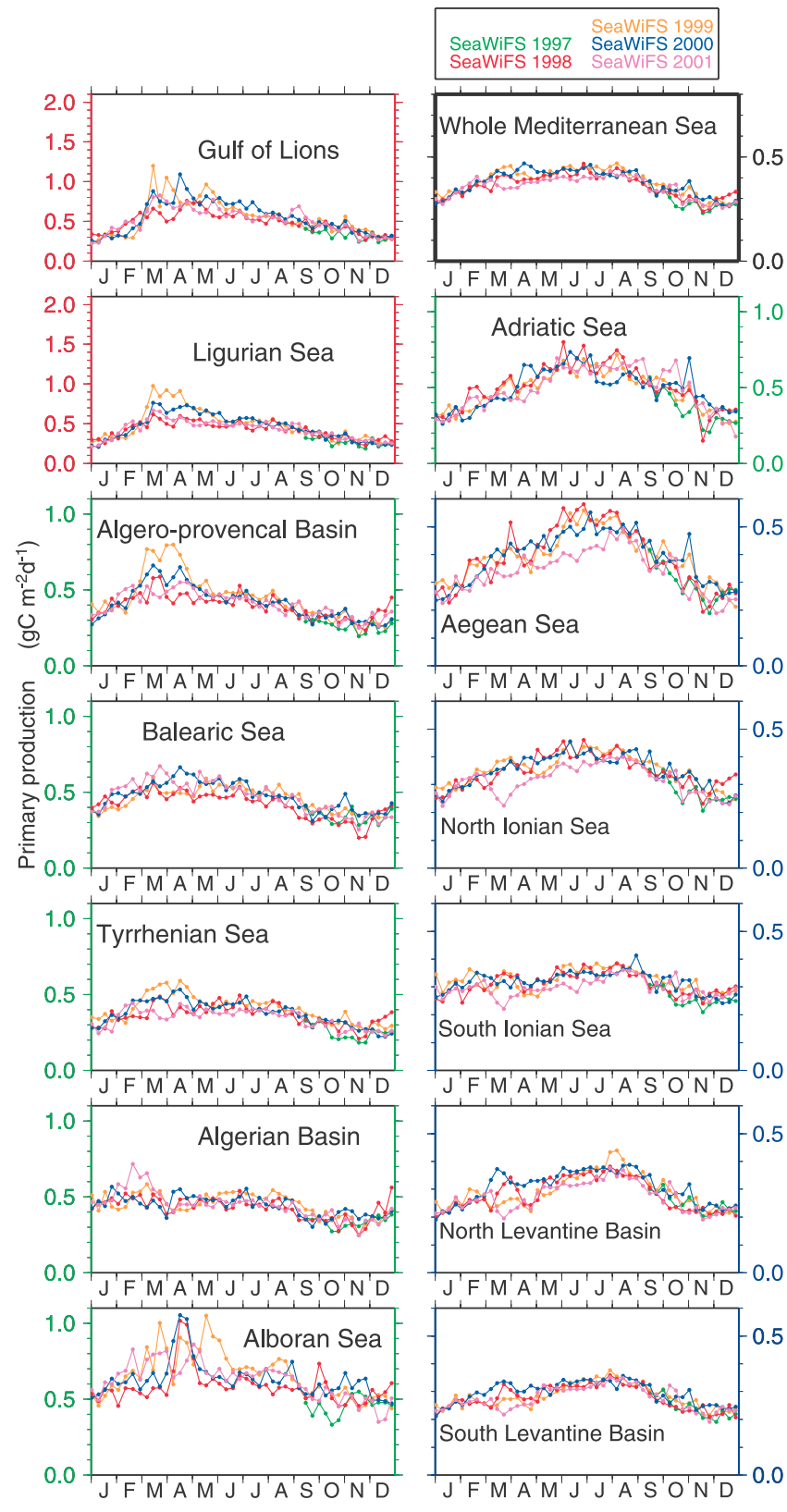

Figure 10. Eight-day averages of the primary production (in $\mathrm{gC} \mathrm{m}^{-2} \mathrm{~d}^{-1}$ ), and averaged over the whole basin and the various regions, along the period September 1997 to December 2001. The values of primary production have been computed for each pixel from the 8-day averages of chlorophyll concentration, of $\operatorname{PAR}\left(0^{+}\right)$, and of the average temperature of the productive layer, and then spatially averaged.

for instance, is clearly visible. This spring maximum is (as expected, since $\mathrm{Chl}_{\text {tot }}$ varies roughly as $\mathrm{Chl}_{\mathrm{sat}}^{0.5}$ ) attenuated with respect to the biomass maximum. It is also considerably weakened compared to that observed by Morel and André [1991], for which the ratio of spring-to-winter values was about a factor of 3 (see Figure 12). This is mostly due to the high biomass values derived from Sea-
WiFS data, which, in spite of low $\operatorname{PAR}\left(0^{+}\right)$values, maintain the primary production at a rather high level during winter months.

[45] In the Eastern Basin, surface biomass in most provinces decreases significantly from winter to summer (and this decrease is enhanced when using the regional algorithm), so that the seasonal courses of PAR and algal biomass tend to compensate each other. As a result, primary production exhibits a weakly marked maximum over summer (Figure 10), in contrast to the observations by Antoine et al. [1995] where this maximum was conspicuous (almost a factor of 3 between winter and summer; see Figure 12).

[46] As the interannual variations of PAR are relatively weak (Figure 4) and those of seawater temperature have a reduced impact, the interannual variations in primary production are, at least during the periods of high variability such as spring in the Western Basin, primarily ruled by those in algal biomass (it is recalled, however, that algal biomass does not evolve independently from other parameters). As mentioned above, variations in primary production are obviously reduced compared to those in biomass. The standard deviations for primary production, over the 4year time series, remain always lower than $20 \%$ for both the Western and Eastern Basins, and even lower than $10 \%$ for a large part of the year (Figure 12).

[47] The presently computed carbon fixation rates can be compared with those derived by Antoine et al. [1995] (Figure 12). It can be observed that the present estimates, albeit not drastically different from the previous ones, are generally lower: The range of variation is $0.30-0.60 \mathrm{gC}$ $\mathrm{m}^{-2} \mathrm{~d}^{-1}$ for the Western Basin (instead of 0.29-0.80 $\mathrm{gC}$ $\mathrm{m}^{-2} \mathrm{~d}^{-1}$ for the previous study), and $0.20-0.40 \mathrm{gC} \mathrm{m}^{-2} \mathrm{~d}^{-1}$ for the Eastern Basin (instead of $0.20-0.52 \mathrm{gC} \mathrm{m}^{-2} \mathrm{~d}^{-1}$ ).

\subsection{Annual Primary Production Values}

[48] The map of annual primary production values (averages of monthly maps over the period September 1997 to December 2001) is shown, along with the map of annual means of surface algal biomass, in Figure 13. The values of annual primary production, for the various regions and the 4-year SeaWiFS time series (as obtained by integration of the 8-day values shown in Figure 10), are given in Table 2. Note that estimates for the two main basins, and for the year 1998, were already provided by Bricaud et al. [2002]. These values, however, have been revised, due to (1) the recent reprocessing of SeaWiFS data, (2) the use of the regional algorithm, and (3) the use of simultaneous (instead of climatological) PAR data.

[49] For the Western Basin, the largest interannual variation is observed from 1998 to $1999(+11 \%)$. This increase is largely due to the exceptional algal bloom which occurred in spring 1999 in the northwest part of the basin (the annual primary production has increased by $15 \%$ in the Ligurian Sea), but not exclusively: Even the southern provinces reveal a significant increase in the annual primary production ( $+5 \%$ in the Algerian Basin, $+13 \%$ in the Alboran Sea), and the Tyrrhenian Sea as well $(+11 \%)$. In these provinces also, the enhanced primary production in 1999 mostly originates from the enhanced biomass values in spring, compared to spring 1998 (see Figure 7), as PAR and 


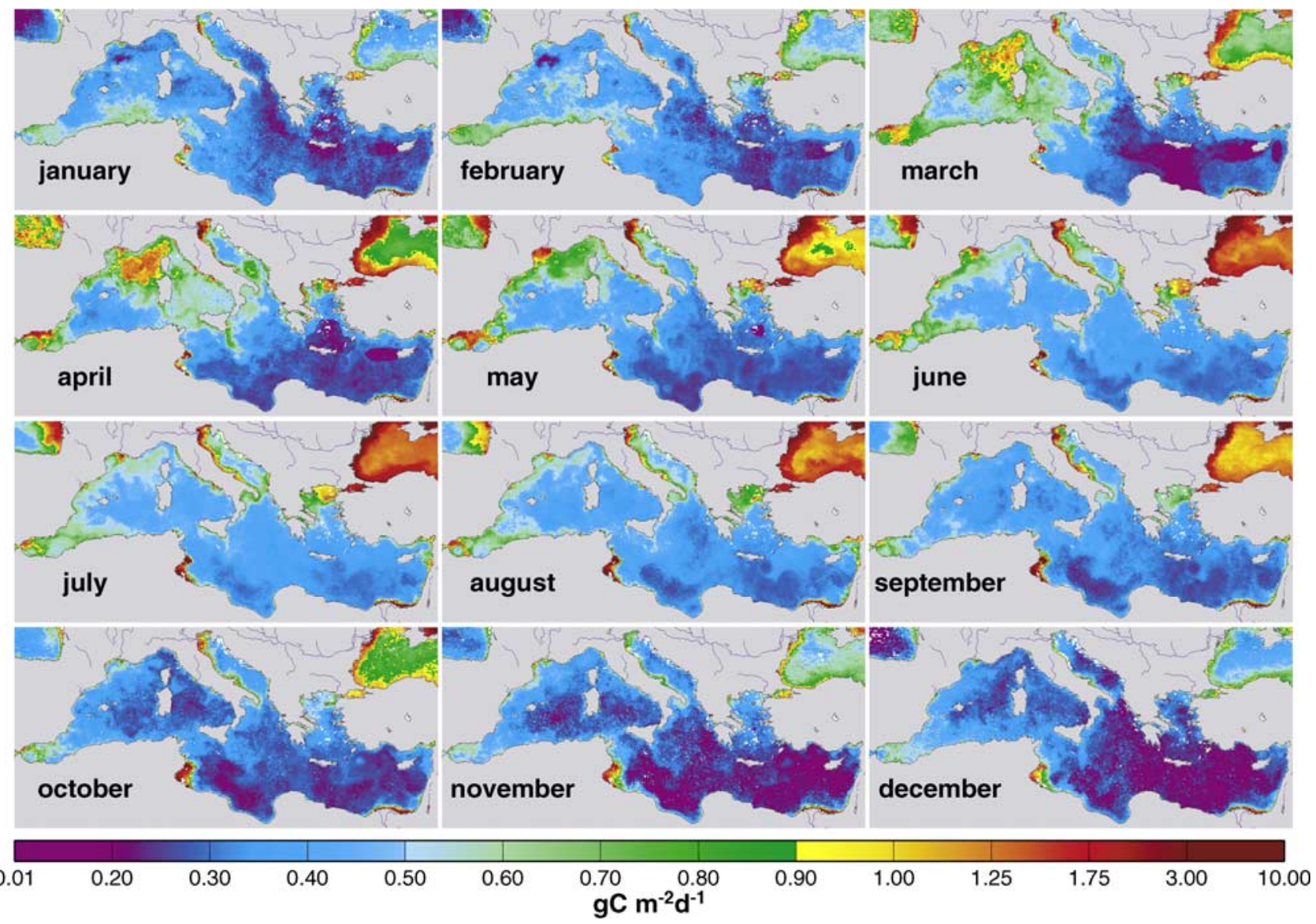

Figure 11. Monthly maps of primary production, for the year 1999.

seawater temperature values were stable from spring 1998 to spring 1999.

[50] For the Eastern Basin, the largest interannual variation occurs from 2000 to $2001(-9 \%)$. At the regional level, the largest decrease is observed for the Aegean Sea (-14\%), the North Levantine Basin $(-11 \%)$, and the North Ionian Sea $(-10 \%)$. For these regions, the 8 -day means of biomass reveal a significant decrease from 2000 to 2001, especially in spring (Figure 7). It is worth noting also that the seawater temperatures are almost systematically higher in 2001 than in 2000 (see Figure 5). These enhanced temperatures may have had a slight impact upon primary production (by enhancing the assimilation number), but more importantly, they probably indicate a stratification of the water column more marked in 2001 than in 2000, which might explain the lower biomass levels.

[51] When comparing the presently derived values with the previous CZCS estimates from Antoine et al. [1995], it is observed that the annual primary production over the period 1998-2001 for the Western Basin $\left(163 \pm 7 \mathrm{gC} \mathrm{m}^{-2}\right.$ $\mathrm{yr}^{-1}$ ) is lower than the CZCS estimate by $17 \%$, while that for the Eastern Basin $\left(121 \pm 5 \mathrm{gC} \mathrm{m}^{-2} \mathrm{yr}^{-1}\right)$ is lower by $12 \%$. Considering the differences in data processings for the two sensors, such slight differences cannot be interpreted from a biogeochemical point of view. It is, however, comforting to note that the annual budgets provided by xAntoine et al. [1995] were (in spite of the CZCS deficiencies) rather realistic. In contrast, the annual primary production values derived from the CZCS standard processing (data from the NASA archive) are higher than the present estimates by $32 \%$ for the Eastern Basin.
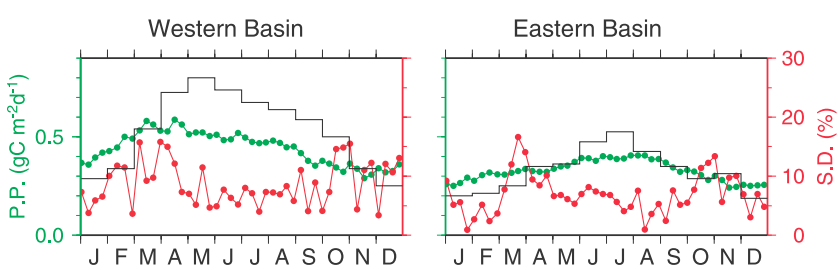

Figure 12. Seasonal variations of primary production (8-day averages computed as in Figure 10), averaged over the different years for the Western and Eastern Basins (green lines, in $\mathrm{gC} \mathrm{m}^{-2} \mathrm{~d}^{-1}$; left scales). The corresponding standard deviations are also shown (red lines, in \%; right scales). The values obtained by Antoine et al. [1995] (from monthly chlorophyll concentrations derived from CZCS data, climatological $\operatorname{PAR}\left(0^{+}\right)$values and seawater temperatures from the Levitus climatology) are shown for comparison (black lines). These values have been multiplied by 1.25 to account for the fact that the value of the ratio of active-to-total chl $a$ has been revised (for oligotrophic and mesotrophic waters, 1.0 instead of 0.8 ) by Morel et al. [1996]. 

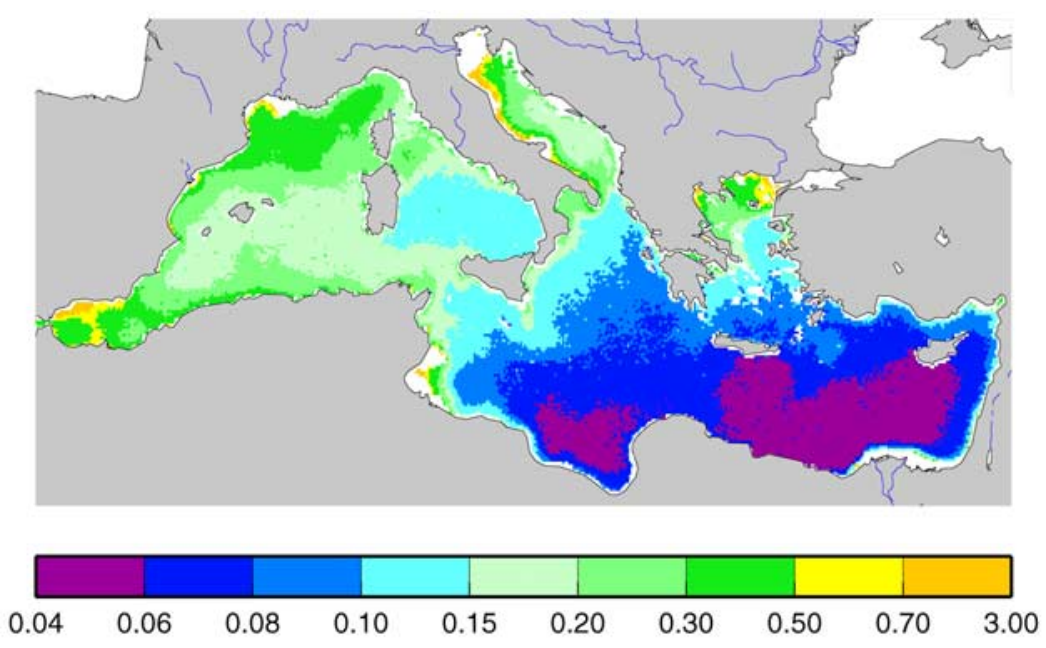

Annual mean of Surface Chl Concentration $\left(\mathrm{mg} \mathrm{m}^{-3}\right)$

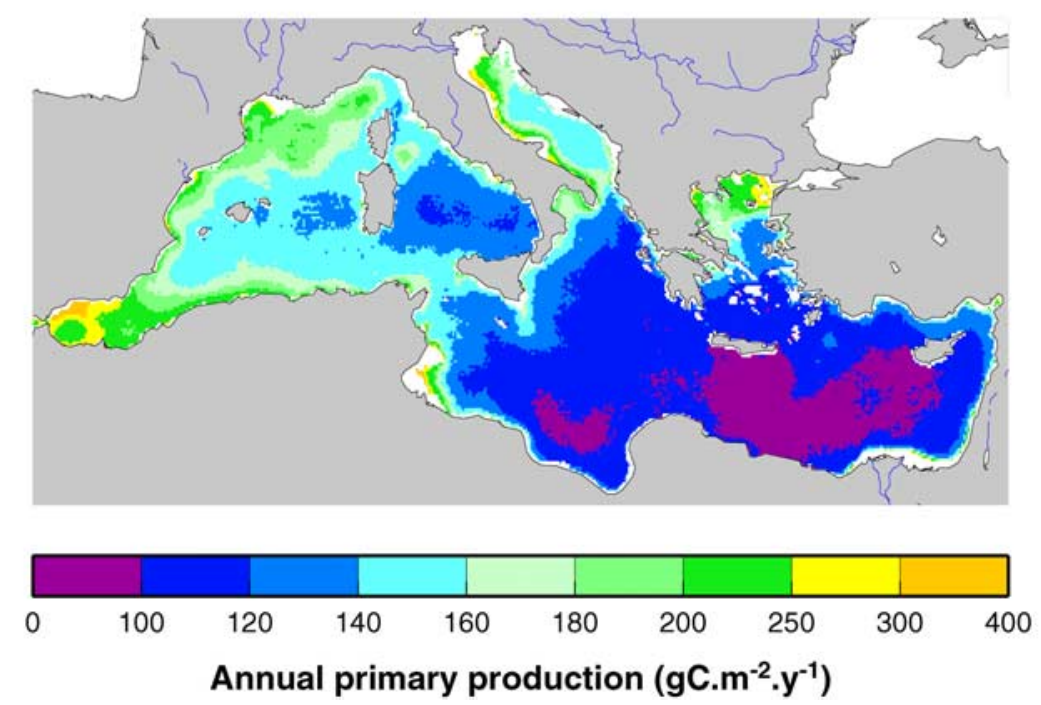

Figure 13. Maps of annual averages of (top) surface algal biomass and (bottom) primary production, computed over the period September 1997 to December 2001. The mask used for turbid-Case 2 waters appears in white.

[52] Some other estimates of annual primary production, based on in situ measurements, CZCS data, or modeling studies for a few regions of the Mediterranean, have been previously proposed. These are compared to our estimates from SeaWiFS data, for similar areas, in Table 3.

[53] The only estimate based on in situ measurements and concerning the whole basin is that of Sournia [1973], which is about 37\% lower than our present estimates. Other published values deal with provinces or sub-provinces. For the Western Basin, the Gulf of Lions and the Ligurian Sea are the most documented regions. For the Gulf of Lions, estimates of Lefèvre et al. [1997] and Conan et al. [1998] are lower than our estimates, by $50 \%$ and $25 \%$, respectively. For the Ligurian Sea, in situ measurements by Marty and Chiaverini [2002] reveal a large interannual variability (a factor of 2.7 over 7 years), and our estimates are included in their range of variation. The estimate provided by Tusseau et al. [1997], based on a coupled physical-biological model of the ecosystem of the Ligurian Sea is in good agreement with our estimate, while that provided by Levy et al. [1998] (for the same area and with the BIOgeochemical Model of the Euphotic Layer of the Lodyc (BIOMELL)) is lower by $40-50 \%$. For the Balearic Sea, the value of annual primary production proposed by Estrada [1996], based on in situ measurements over 11 years (1983-1993), is in excellent agreement with our estimate.

[54] The previously published estimates for the Eastern Mediterranean deal mainly with the Levantine Basin. The value provided by Dowidar [1984] from in situ measurements is lower than our estimates by a factor of 2, while those derived by Van Dijken and Arrigo [1996] from CZCS data, and by Napolitano et al. [2000] using a physicalbiological model, are consistent with SeaWiFS estimates. The estimates of Psarra et al. [2000] for the Cretan Sea, 
Table 2. Annual Primary Production (in $\mathrm{gC} \mathrm{m}^{-2} \mathrm{yr}^{-1}$ ) for the Mediterranean Basin and the Various Regions, as Estimated From the 4-year SeaWiFS Time Series, by Integrating the 8-Day Averages of Primary Production (see Figure 10) Over Each Year $^{\mathrm{a}}$

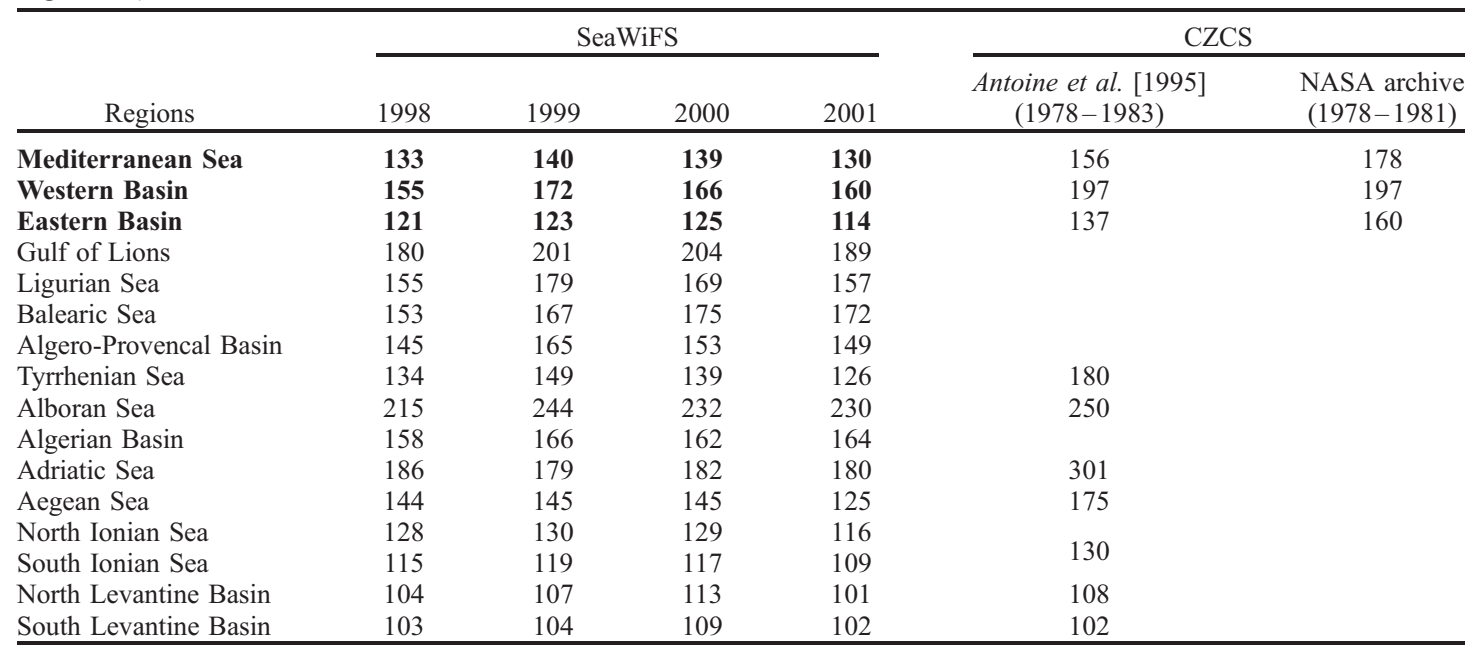

${ }^{a}$ The previous estimates made by Antoine et al. [1995] and André and Morel [1991] (using the CZCS chlorophyll estimates pooled over the 1979-1983 period, climatological data for $\operatorname{PAR}\left(0^{+}\right)$and the Levitus data set for seawater temperature) are shown for comparison (the values have been corrected by a factor 1.25 to account for the revised value of the ratio of active-to-total chl $a$; see Figure 12 caption). The values have been reported only for the regions delimited in the same way as in the present study. The estimates obtained from the NASA archive (monthly composites from 1978 to 1981) are also shown.

which show a large interannual variability over 1994 and 1995 (59 to $80 \mathrm{gC} \mathrm{m}^{-2} \mathrm{yr}^{-1}$ ) are also bracketing the SeaWiFS estimates.

[55] In addition to the interannual variations of primary production, which may account for part of the observed differences, numerous reasons may explain the divergences. In the present estimates using SeaWiFS data, the main sources of error are the uncertainty still affecting the biomass values derived from SeaWiFS (i.e., the uncertainty in atmospheric corrections and bio-optical algorithm), the use of constant physiological parameters in the light-photosynthesis model [Morel et al., 1996], and (to lesser extent) the extrapolation of surface algal biomass to in-depth values. For in situ primary production measurements, in addition to possible errors attached to the methods (e.g., exposure of deep samples to intense light during the hauling onboard of the line [Marty and Chiaverini, 2002]), the extrapolation of measurements (over a few hours) to daily values, and of measurements limited in time and space to estimate annual values for a large area, is also expected to be a large source of error. Considering these various sources of divergences, the consistency between some published values and the SeaWiFS estimates of annual primary production observed in Table 3 is rather encouraging.

\section{Conclusions}

[56] Thanks to the unprecedented time series of ocean color data provided by the SeaWiFS sensor, the seasonal and interannual variations of algal biomass and primary production could be studied over the various regions of the Mediterranean Basin. These estimates are believed to be more accurate than the previously published ones, because of (1) the higher radiometric quality and temporal resolution

Table 3. Published Values of Annual Primary Production (in $\mathrm{gC} \mathrm{m} \mathrm{m}^{-2} \mathrm{yr}^{-1}$ ) for Various Regions of the Mediterranean, as Compared to Our Estimates Using SeaWiFS Data (for Similar Areas and Over the Period 1998-2001)

\begin{tabular}{|c|c|c|c|c|c|}
\hline References & Area & Period & Method & \multicolumn{2}{|c|}{ Annual $\mathrm{PP}, \mathrm{gC} \mathrm{m}^{-2} \mathrm{yr}^{-1}$} \\
\hline Sournia [1973] & whole basin & climatological & ${ }^{14} \mathrm{C}$ & $80-90$ & $130-140$ \\
\hline Estrada [1996] & Balearic Sea & $1983-1993$ & ${ }^{14} \mathrm{C}$ (Let-Go) & 158 & $153-175$ \\
\hline van Dijken and Arrigo [1996] & south Levantine Basin & $1978-1985$ & CZCS data & 82 & $102-109$ \\
\hline Lefèvre et al. [1997] & Gulf of Lions & climatological & ${ }^{14} \mathrm{C}$ & $78-142$ & $180-204$ \\
\hline Conan et al. [1998] & Gulf of Lions & 1993 & ${ }^{14} \mathrm{C}$ (Let-Go) & $140-150$ & $188-202$ \\
\hline Levy et al. [1998] & Ligurian Sea & 1991 & modeling & 106 & $188-213$ \\
\hline Napolitano et al. [2000] & north Levantine Basin & & modeling & 97 & $101-113$ \\
\hline Psarra et al. [2000] & Cretan Sea & $1994-1995$ & ${ }^{14} \mathrm{C}$ (Let-Go) & $59-80$ & $63-67$ \\
\hline Marty and Chiaverini [2002] & Ligurian Sea & $1993-1999$ & ${ }^{14} \mathrm{C}$ (Let-Go) & $86-232$ & $188-213$ \\
\hline
\end{tabular}


of SeaWiFS data, compared to CZCS, (2) the improvement in algorithms and data processing procedures, and (3) the availability of simultaneous PAR and sea surface temperature data, which allows the carbon fixation rates to be refined. Also, the specific bio-optical behavior of Mediterranean waters could be taken into account, by using a regional algorithm instead of the standard algorithm $(\mathrm{OC} 4 \mathrm{v} 4)$ in use for the world ocean. This study has revealed significant interannual variations in biomass and primary production, not only in the Northwestern Basin (e.g., the exceptional bloom in spring 1999), but also, and more surprisingly, in the oligotrophic waters of the Eastern Basin (e.g., the $9 \%$ decrease in primary production from 2000 to 2001).

[57] The present study has also revealed many common points, but also some noticeable differences with the results of the previous studies based on CZCS data [Morel and André, 1991; Antoine et al., 1995]. The seasonal cycles of algal biomass, in particular, are in most regions substantially different from those described in the previous studies. Such divergences are likely due to differences in data processing (mainly calibration and atmospheric correction schemes). Some other differences, however, are not dependent on the processing procedures, and therefore might reveal a longterm evolution of the ecosystems in response to environmental changes: The most conspicuous features are the reduction of the deep convection zone, the earlier start of the spring bloom, and the quasi-absence of the autumn bloom.

[58] These differences, although conspicuous at the regional and seasonal level, have, however, a relatively weak impact upon the annual primary production values. The present estimates, as derived from the 4-year SeaWiFS time series, are lower than those derived from CZCS data (by 17 and $12 \%$ for the Western and Eastern Basins, respectively). It is presently difficult to state whether this difference, over a 20-year period, is actual, or only results from the differences in data processing for the two sensors. The answer to such a question will be given only when a longer and more homogeneous time series of ocean color data is available. Studying the long-term trends in algal biomass and primary production will probably need a combination of data from different sensors, and the effort initiated by programs such as SIMBIOS (Sensor Intercomparison and Merger for Biological and Interdisciplinary Oceanic Studies [Fargion et al., 1999]), to make consistent and merge data from various sources, will have to be pursued.

[59] There still exists some uncertainty upon the present estimates, as some problems, specific to the Mediterranean Basin, remain to be solved. The specific bio-optical behavior of the Mediterranean waters has been observed by various authors, and different explanations were proposed (e.g., presence of desert dust in surface waters, or CDOM content larger than expected). When the origin of this phenomenon is clearly identified, it will be possible to know whether the regional algorithm can be safely applied for all regions and periods, or if the optical properties of surface waters are varying in a still more complex way. In addition, the comparison with in situ data has shown that the chlorophyll estimates derived from SeaWiFS data are still overestimated by up to a factor of 2 in oligotrophic waters. As stated before, this error is likely mostly due to inaccurate atmospheric corrections, and the presence of absorbing aerosols (desert dust) over the Mediterranean could be responsible for such errors [Moulin et al., 2001]. These problems have still to be tackled for a proper use of ocean color data and refined estimates of the carbon budgets for the Mediterranean Basin.

[60] Acknowledgments. The authors thank NASA and the SeaWiFS Project for providing SeaWiFS data. They acknowledge the financial support from CNRS and Region PACA, through a grant to E. B. We thank A. Morel for suggestions on the manuscript, and three anonymous referees for their constructive comments. This work is a contribution to the ESPER and PROSOPE projects, which were funded by the PROOF (JGOFSFrance) national program.

\section{References}

André, J. M., and A. Morel (1991), Atmospheric corrections and interpretation of marine radiances in CZCS imagery, revisited, Oceanol. Acta, 14, $3-22$.

Antoine, D., and A. Morel (1996), Oceanic primary production: I. Adaptation of a spectral light-photosynthesis model in view of application to satellite chlorophyll observations, Global Biogeochem. Cycles, 10, $43-$ 55

Antoine, D., A. Morel, and J. M. André (1995), Algal pigment distribution and primary production in the eastern Mediterranean as derived from Coastal Zone Color Scanner observations, J. Geophys. Res., 100, 16,193-16,209.

Arnone, R. A., D. A. Wiesenburg, and K. D. Saunders (1990), The origin and characteristics of the Algerian Current, J. Geophys. Res., 95, 15871598 .

Azov, Y. (1986), Seasonal patterns of phytoplankton productivity and abundance in nearshore oligotrophic waters of the Levant basin (Mediterranean), J. Plankton Res., 8, 41-53.

Berman, T., Y. Azov, A. Schneller, P. Walline, and D. W. Townsend (1986), Extent, transparency, and phytoplankton distribution of the neritic waters overlying the Israeli coastal shelf, Oceanol. Acta., 9, 439-447.

Béthoux, J. P., P. Morin, C. Chaumery, O. Connan, B. Gentili, and D. RuizPino (1998), Nutrients in the Mediterranean Sea, mass balance and statistical analysis of concentrations with respect to environmental change, Mar. Chem., 63, 155-169.

Béthoux, J. P., B. Gentili, P. Morin, E. Nicolas, C. Pierre, and D. Ruiz-Pino (1999), The Mediterranean Sea: A miniature ocean for climatic and environmental studies and a key for the climatic functioning of the North Atlantic, Prog. Oceanogr., 44, 131-146.

Bosc, E. (2002), Variations saisonnières et interannuelles de la biomasse phytoplanctonique et de la production primaire en Méditerranée: Evaluation et utilisation des données satellitales de couleur de l'océan (SeaWiFS, POLDER et OCTS), Thèse de Doctorat, 203 pp., Univ. Pierre et Marie Curie, Paris.

Bricaud, A., E. Bosc, and D. Antoine (2002), Algal biomass and sea surface temperature in the Mediterranean Basin: Intercomparison of data from various satellite sensors, and implications for primary production estimates, Remote Sens. Environ., 81, 163-178.

Claustre, H., A. Morel, S. B. Hooker, M. Babin, D. Antoine, K. Oubelkheir, A. Bricaud, K. Leblanc, B. Quéguiner, and S. Maritorena (2002), Is desert dust making oligotrophic waters greener?, Geophys. Res. Lett., 29(10), 1469, doi:10.1029/2001GL014056.

Conan, P., M. Pujo-Pay, P. Raimbault, and M. Leveau (1998), Variabilité hydrologique et biologique au sein du courant nord-mediterranéen à l'entrée du golfe du Lion: Bilan de la productivité sur le bord interne du courant, Oceanologica Acta, 21, 767-782.

Corsini, G., R. Grasso, and P. Cipollini (2002), Regional bio-optical algorithms for the Alboran Sea from a reflectance model and in situ data, Geophys. Res. Lett., 29(15), 1739, doi:10.1029/2001GL013861.

D'Ortenzio, F., R. Santoleri, S. Marullo, M. Ragni, and M. Ribera d'Alcalà (2001), Empirical SeaWiFS algorithm validation for the Mediterranean Sea, poster presented at SIMBIOS meeting, Natl. Aeronaut. and Space Admin., Washington, D. C., 29-31 January.

D’Ortenzio, F., S. Marullo, M. Ragni, M. Ribera d'Alcalà, and R. Santoleri (2002), Validation of empirical SeaWiFS algorithms for chlorophyll a retrieval in the Mediterranean Sea: A case study for oligotrophic seas, Remote Sens. Environ., 82, 79-94. 
Dowidar, N. M. (1984), Phytoplankton biomass and primary productivity of the southeastern Mediterranean, Deep Sea Res., 31, 983-1000.

Estrada, M. (1996), Primary production in the northwestern Mediterranean, Sci. Mar., 60, 55-64.

Evans, R. H., and H. R. Gordon (1994), CZCS "system calibration": A retrospective examination, J. Geophys. Res., 99, 7293-7307.

Fargion, G. S., C. R. McClain, H. Fukushima, J. M. Nicolas, and R. A. Barnes (1999), Ocean color instrument intercomparisons and cross-calibrations by the SIMBIOS Project, paper presented at EOS/SPIE Symposium on Remote Sensing, Eur. Opt. Soc., Barcelona, Spain, 20-24 September. (Available at http://simbios.gsfc.nasa.gov/Info/Publications.html)

Garcia-Gorriz, E., and M. E. Carr (1999), The climatological annual cycle of satellite-derived phytoplankton pigments in the Alboran Sea, Geophys. Res. Lett., 26, 2985-2988.

Garcia-Gorriz, E., and M. E. Carr (2001), Physical control of phytoplankton distributions in the Alboran Sea: A numerical and satellite approach, J. Geophys. Res., 106, 16,795-16,805.

Gitelson, A., A. Karnieli, N. Goldman, Y. Z. Yacobi, and M. Mayo (1996), Chlorophyll estimation in the Southeastern Mediterranean using CZCS images: Adaptation of an algorithm and its validation, J. Mar. Syst., 9, $283-290$.

Gordon, H. R., and M. Wang (1994), Retrieval of water-leaving radiance and aerosol optical thickness over the oceans with SeaWiFS: A preliminary algorithm, Appl. Opt., 33, 443-452.

Gordon, H. R., D. K. Clark, J. W. Brown, R. H. Evans, and W. W. Broenkow (1983), Phytoplankton pigment concentrations in the Middle Atlantic Bight: Comparison of ship determinations and CZCS estimates, Appl. Opt., 22, 20-36.

Hooker, S. B., W. E. Esaias, G. C. Feldman, W. W. Gregg, and C. R. McClain (1992), An overview of SeaWiFS and ocean color, NASA Tech. Memo. 104566, vol. 1, edited by S. B. Hooker and E. R. Firestone, 24 pp., NASA Goddard Space Flight Cent., Greenbelt, Md.

Lacombe, H. (1990), A model of the world ocean, water, salt heat, and wind in the Mediterranean, Oceanus, 33, 26-36.

Lacombe, H., and P. Tchernia (1972), Quelques traits généraux de l'hydrologie méditerranéenne d'après diverses campagnes hydrologiques récentes en Méditerranée, dans le proche Atlantique et dans le détroit de Gibraltar, Cah. Oceanogr., 12, 527-547.

Lefèvre, D., H. J. Minas, M. Minas, C. Robinson, P. J. L. B. Williams, and E. M. S. Woodward (1997), Review of gross community production, primary production, net community production and dark community respiration in the Gulf of Lions, Deep Sea Res., Part II, 44, $801-832$.

Levitus, S. (1982), Climatological atlas of the world ocean, NOAA Prof. Pap. 13, U.S. Govt. Print. Off., Washington, D. C.

Levy, M., L. Memery, and J. M. André (1998), Simulation of primary production and export fluxes in the northwestern Mediterranean Sea, J. Mar. Res., 56, 197-238.

Marty, J.-C., and J. Chiaverini (2002), Seasonal and interannual variations in phytoplankton production at DYFAMED time-series station, northwestern Mediterranean Sea, Deep Sea Res., Part II, 49, 20172030.

Marullo, S., R. Santoleri, P. Malanotte-Rizzoli, and A. Bergamasco (1999), The sea surface temperature field in the Eastern Mediterranean from advanced very high resolution radiometer (AVHRR) data: II. Interannual variability, J. Mar. Syst, 20, 83-112.

McClain, C. R., M. L. Cleave, G. C. Feldman, W. W. Gregg, and S. H. Hooker (1998), Science quality SeaWiFS data for global biosphere research, Sea Technol., 39, 10-16.

Morel, A. (1988), Optical modeling of the upper ocean in relation to its biogenous matter content (case 1 waters), J. Geophys. Res., 93, 10,74910,768 .

Morel, A. (1991), Light and marine photosynthesis: A spectral model with geochemical and climatological implications, Prog. Oceanogr. $26,263-306$
Morel, A., and J. M. André (1991), Pigment distribution and primary production in the western Mediterranean as derived and modeled from Coastal Zone Color Scanner observations, J. Geophys. Res., 96, $12,685-12,698$

Morel, A., and J. F. Berthon (1989), Surface pigments, algal biomass profiles, and potential production of the euphotic layer: Relationships reinvestigated in view of remote sensing applications, Limnol. Oceanogr., 34, $1541-1564$

Morel, A., D. Antoine, M. Babin, and Y. Dandonneau (1996), Measured and modeled primary production in the Northeast Atlantic (EUMELI JGOFS program): The impact of natural variations in photosynthetic parameters on model predictive skill, Deep Sea Res., Part I, 43, 1273 1304.

Moulin, C., H. R. Gordon, R. M. Chomko, V. F. Banzon, and R. H. Evans (2001), Atmospheric correction of ocean color imagery through thick layers of Saharan dust, Geophys. Res. Lett., 28, 5-8.

Napolitano, E., T. Oguz, P. Malanotte-Rizzoli, A. Yilmaz, and E. Sansone (2000), Simulations of biological production in the Rhodes and Ionian basins of the eastern Mediterranean, J. Mar. Syst., 24, 277-298.

O'Reilly, J. E., S. Maritorena, B. G. Mitchell, D. A. Siegel, K. L. Carder, S. A. Garver, M. Kahru, and C. McClain (1998), Ocean color chlorophyll algorithms for SeaWiFS, J. Geophys. Res., 103, 24,937-24,953.

Ozsöy, E., A. Hecht, Ü. Ünlüata, S. Brenner, H. I. Sur, J. Bishop, M. A. Latif, Z. Robenstraub, and T. Oguz (1993), A synthesis of the Levantine Basin circulation and hydrography, 1985-1990, Deep Sea Res., 40, 1075-1119.

POEM Group (1992), General circulation of the eastern Mediterranean, Earth Sci. Rev., 32, 285-309.

Preller, R. H. (1986), A numerical study of the Alboran Sea gyre, Prog. Oceanogr., 16, 113-146.

Psarra, S., A. Tselepides, and L. Ignatiades (2000), Primary productivity in the oligotrophic Cretan Sea (NE Mediterranean): Seasonal and interannual variability, Prog. Oceanogr., 46, 187-204.

Reynolds, R. W., and T. M. Smith (1995), A high-resolution global sea surface temperature climatology, J. Clim., 8, 1571-1583.

Roether, W., B. B. Manca, B. Klein, D. Bregant, D. Georgopoulos, V. Beitzel, V. Kovacevic, and A. Luchetta (1996), Recent changes in eastern Mediterranean deep waters, Science, 271, 333-335.

Rossow, W. B., A. W. Walker, D. E. Beuschel, and M. D. Roiter (1996) Documentation of new cloud datasets, report, 115 pp., Int. Satellite Cloud Climatol. Project, NASA Goddard Space Flight Cent., Greenbelt, Md.

Siegel, D. A., M. Wang, S. Maritorena, and W. Robinson (2000), Atmospheric correction of satellite ocean color imagery: The black pixel assumption, Appl. Opt., 39, 3582-3591.

Sournia, A. (1973), La production primaire planctonique en Méditerranée: Essai de mise à jour, Bull. Etude Commun. Mediter., 5, 1-128.

Tusseau, M. H., C. Lancelot, J. M. Martin, and B. Tassin (1997), 1-D coupled physical-biological model of the northwestern Mediterranean Sea, Deep Sea Res., Part II, 44, 851-880.

Van Dijken, G. L., and K. R. Arrigo (1996), Ocean color remote sensing of the southeastern Mediterranean Sea, Eos Trans. AGU, 76(3), Suppl., 167.

Vidussi, F. (1998), Variabilité spatiale et temporelle des marqueurs pigmentaires des communautés autotrophes en Méditerranée: Implications biogéochimiques, Thèse de Doctorat, 181 pp., Univ. Pierre et Marie Curie, Paris.

Vidussi, F., H. Claustre, B. Manca, A. Luchetta, and J.-C. Marty (2001), Phytoplankton pigment distribution in relation to the upper thermocline circulation in the eastern Mediterranean Sea during winter, J. Geophys. Res., 106, 19,939-19,956.

D. Antoine, E. Bosc, and A. Bricaud, Laboratoire d'Océanographie de Villefranche, BP 8, CNRS and Université Pierre et Marie Curie, F-06238 Villefranche-sur-Mer Cedex, France. (annick@obs-vlfr.fr) 